\title{
Zooarchaeology and taphonomy of FLK North 5
}

By: Charles P. Egeland

Egeland C.P. (2007) Zooarchaeology and taphonomy of FLK North 5. In (M. DomínguezRodrigo, R. Barba \& C.P. Egeland) Deconstructing Olduvai: A Taphonomic Study of the Bed I Sites. Vertebrate Paleobiology and Paleoanthropology. Springer, Dordrecht, pp. 191-200. https://doi.org/10.1007/978-1-4020-6152-3_10

\section{$* * *$ (C) 2007 Springer. Reprinted with permission. No further reproduction is authorized without written permission from Springer. This version of the document is not the version of record. $* * *$}

\begin{abstract}
:
The assemblage from Level 5 of the FLK North locality is particularly interesting because unlike many Bed I sites (except FLK North North Level 1, see Chapter 12), no systematic taphonomic data have been presented for the large mammal subassemblage since Leakey's (1971) monograph (see Fernández-Jalvo et al., 1998 for a discussion of small mammals). Therefore, and despite the fact that both cut marks and tooth marks have been identified in the large mammal subassemblage (Potts and Shipman, 1981; Shipman, 1983, 1986), the roles of hominids and carnivores in site formation are poorly understood. Although Shipman (1986) identified three cut-marked bovid specimens, this expanded analysis identified only one specimen preserving definitive cut marks and little to no evidence for hominid bonebreaking activities. Therefore, like the other large mammal subassemblages from the FLK North site, Level 5 can securely be attributed almost solely to the activities of carnivores.
\end{abstract}

Keywords: taphonomy | Olduvai | Plio-Pleistocene | bone surface modifications | zooanthropology

\section{Chapter:}

\section{Introduction}

The assemblage from Level 5 of the FLK North locality is particularly interesting because unlike many Bed I sites (except FLK North North Level 1, see Chapter 12), no systematic taphonomic data have been presented for the large mammal subassemblage since Leakey's (1971) monograph (see Fernández-Jalvo et al., 1998 for a discussion of small mammals). Therefore, and despite the fact that both cut marks and tooth marks have been identified in the large mammal subassemblage (Potts and Shipman, 1981; Shipman, 1983, 1986), the roles of hominids and carnivores in site formation are poorly understood. Although Shipman (1986) identified three cut-marked bovid specimens, this expanded analysis identified only one specimen preserving definitive cut marks and little to no evidence for hominid bone-breaking activities. Therefore, like the other large mammal subassemblages from the FLK North site, Level 5 can securely be attributed almost solely to the activities of carnivores. 


\section{The FLK North 5 Faunal Assemblage}

\section{SITE DISTURBANCE AND INTEGRITY}

A predominance of fragments preserving less than half the original diaphyseal circumference (Type 1) indicate that the assemblage is unbiased by selective retention (Marean et al., 2004) (Figure 113). Figure 114 shows that fragments $<4 \mathrm{~cm}$ are slightly less well-represented than expected based on comparisons with experimental assemblages (Blumenschine, 1995; Pickering and Egeland, 2006). Only three specimens ( $0.2 \%$ of total NISP) exhibit the polishing indicative of extensive water transport. Compared to other sites such as DK (see Chapter 15), FLK North 5, along with the other assemblages in the FLK North sequence (see Chapters 7-9), experienced relatively low levels of postdepositional disturbance.

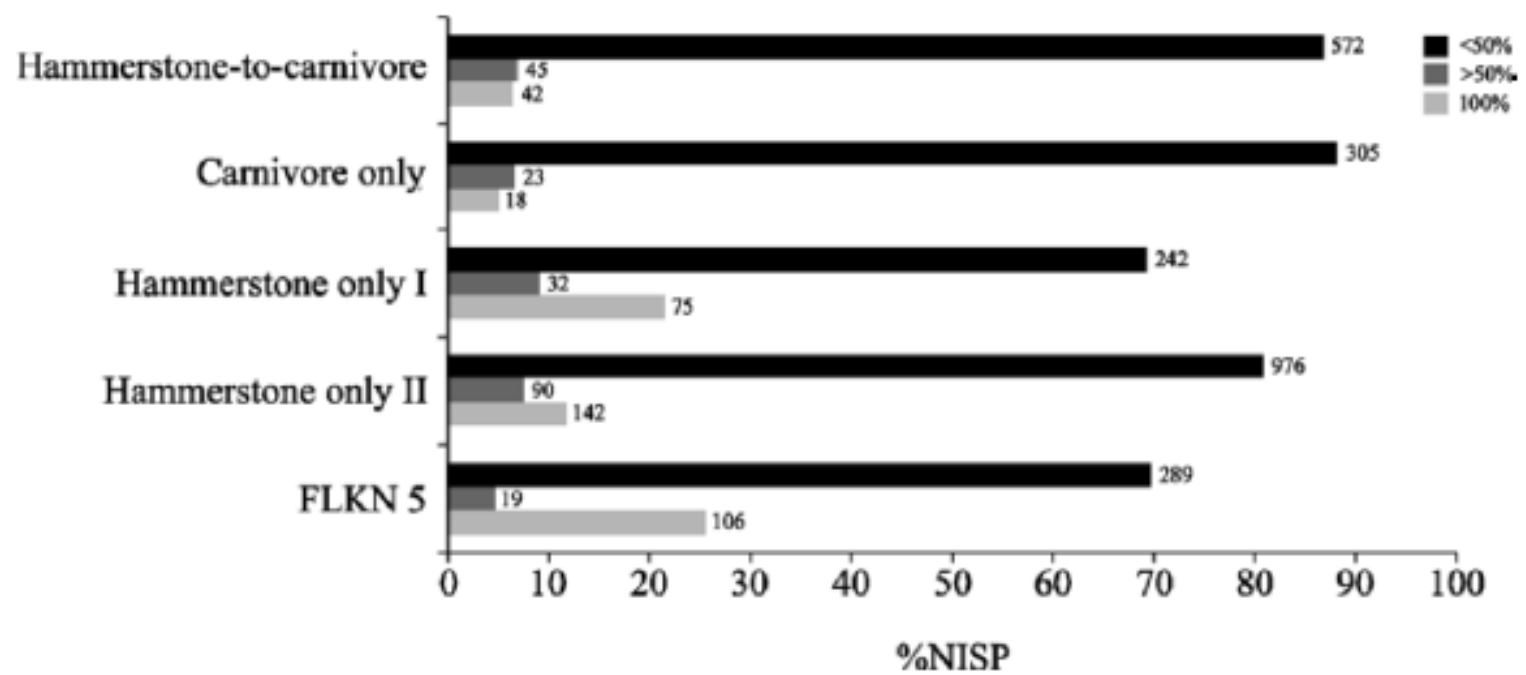

Figure 113. The percentage of Bunn's (1982) limb bone circumference types in the FLK North 5 assemblage compared to several experimental samples. Carnivore only, hammerstone-to-carnivore, and hammerstone only I samples from Marean et al. (2004). Hammerstone only II sample from Pickering and Egeland (2006).

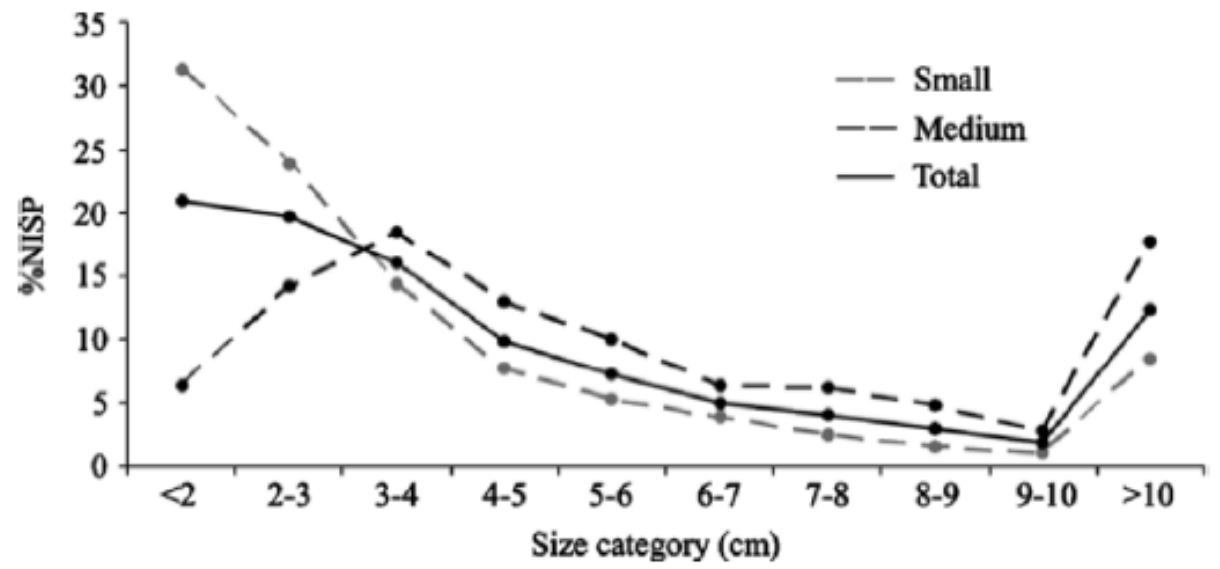

Figure 114. Percentage of specimens in each size range category at FLK North 5. Data are divided into specimens from small carcasses, medium carcasses, and combined. 
Table 47 summarizes the relative abundance of major faunal groups at FLK North 5. Bovids and carnivores are particularly well represented in the assemblage. Table 48 provides minimum number of individuals (MNI) estimates. Like the levels below it, the FLK North 5 fauna is dominated by Antidorcas recki and Parmularius altidens, perhaps suggesting a specialized bonecollecting agent.

Patterns of skeletal element representation also suggest that the bovids experienced a different taphonomic history than the suid subassemblage, which is dominated by teeth (Table 49). Relative to the number of individuals, skulls and limb bones are the most well-represented skeletal elements for both small (Size Class 1 and 2) and medium (Size Class 3a and 3b) carcasses, whereas axial bones are poorly represented (Table 50). According to Marean and Spencer's (1991) limb bone portions, midshafts provide the highest minimum number of element (MNE) estimate for all small-sized limb bones and for all but the metapodials for medium-sized carcasses (Table 51).

Table 47. Number of identified specimens (NISP) for major faunal groups at FLK North 5

\begin{tabular}{|lcc|}
\hline Faunal group & NISP & \% \\
\hline Bovidae & 909 & 76.2 \\
Suidae & 81 & 6.8 \\
Equidae & 1 & 0.1 \\
Carnivora & 202 & 16.9 \\
\hline
\end{tabular}

Table 48. Minimum number of individuals (MNI) represented at FLK North 5

\begin{tabular}{|lc|}
\hline Taxon & MNI \\
\hline A. recki & 18 \\
P. altidens & 5 \\
Beatragus sp. & 1 \\
Size 1 Neotragini & 1 \\
Size 3b Tragelapini & 2 \\
Size 3b Alcelaphini & 3 \\
Size 3 Hippotragini & 1 \\
Prototocyon recki & 1 \\
Kolpochoerus limnetes & 2 \\
\hline
\end{tabular}

Table 49. Number of identified specimens (NISP) by skeletal element for bovids and suids at FLK North 5

\begin{tabular}{|lcc|}
\hline Element & Bovidae & Suidae \\
\hline Cranium & 40 & 2 \\
Teeth & 165 & 49 \\
Mandible & 22 & 5 \\
Vertebrae & 19 & 2 \\
Ribs & 10 & 3 \\
Innominate & 23 & - \\
Scapula & 15 & 3 \\
Humerus & 21 & 2 \\
Radio-ulna & 51 & 2 \\
Carpals/tarsals & 127 & - \\
Metacarpal & 42 & - \\
Femur & 32 & - \\
Tibia & 57 & - \\
\hline
\end{tabular}




\begin{tabular}{|lcc|}
\hline Element & Bovidae & Suidae \\
\hline Metatarsal & 61 & - \\
Patella & 5 & - \\
Phalangers & 145 & 13 \\
Sesamoids & 54 & - \\
Metapodial & 18 & - \\
Limb bone shaft & 2 & - \\
\hline
\end{tabular}

Table 50. Minimum number of element (MNE) estimates for small (Size Class 1 and 2) and medium (Size Class 3) carcasses at FLK North 5

\begin{tabular}{|lccc|}
\hline Element & Small & Medium & Total \\
\hline Cranium & 19 & 7 & 26 \\
Mandible & 16 & 7 & 23 \\
Vertebrae & 14 & 18 & 32 \\
Innominate & 17 & 4 & 21 \\
Ribs & 5 & 8 & 13 \\
Scapula & 13 & 3 & 16 \\
Humerus & 13 & 14 & 27 \\
Radius & 19 & 10 & 29 \\
Ulna & 9 & 9 & 18 \\
Carpals & 33 & 17 & 50 \\
Metacarpal & 17 & 13 & 30 \\
Femur & 10 & 12 & 22 \\
Patella & 6 & 2 & 8 \\
Tibia & 23 & 17 & 40 \\
Tarsals & 47 & 28 & 75 \\
Metatarsal & 20 & 16 & 36 \\
Phalanges & 119 & 18 & 137 \\
Sesamoids & 35 & 20 & 55 \\
\hline
\end{tabular}

Table 51. Minimum number of element (MNE) estimates for limb bones by bone portion for small (Size Class 1 and 2) and medium (Size Class 3) carcasses at FLK North 5

\begin{tabular}{|lccc|}
\hline Element & Small & Medium & Total \\
\hline Humerus & & & \\
PR & 2 & 0 & 2 \\
PRS & 3 & 2 & 5 \\
SH & 11 & 14 & 25 \\
DSS & 12 & 8 & 20 \\
DS & 12 & 5 & 17 \\
Radius & & & \\
PR & 12 & 5 & 17 \\
PRS & 12 & 7 & 19 \\
SH & 16 & 10 & 26 \\
DSS & 8 & 4 & 12 \\
DS & 3 & 3 & 6 \\
Metacarpal & & & \\
PR & 14 & 12 & 26 \\
PRS & 12 & 8 & 20 \\
SH & 16 & 12 & 28 \\
DSS & 12 & 7 & 19 \\
DS & 6 & 7 & 13 \\
Femur & & & \\
PR & 5 & 3 & 3 \\
PRS & 1 & 2 & \\
\hline
\end{tabular}




\begin{tabular}{|lccc|}
\hline Element & Small & Medium & Total \\
\hline SH & 8 & 11 & 19 \\
DSS & 7 & 9 & 16 \\
DS & 7 & 5 & 12 \\
Tibia & & & \\
PR & 4 & 4 & 8 \\
PRS & 7 & 14 & 21 \\
SH & 19 & 15 & 34 \\
DSS & 10 & 12 & 22 \\
DS & 10 & 8 & 18 \\
Metatarsal & & & \\
PR & 17 & 12 & 29 \\
PRS & 16 & 13 & 29 \\
SH & 20 & 12 & 32 \\
DSS & 18 & 7 & 25 \\
DS & 13 & 5 & 18 \\
\hline
\end{tabular}

Abbreviations: PR, proximal; PRS, proximal shaft; SH, midshaft; DSS, distal shaft; DS, distal

\section{BONE SURFACE MODIFICATIONS}

As in many of the Bed I assemblages, cortical surface preservation at FLK North 5 is good. Of those specimens scored for surface preservation, only $30.8 \%$ were considered to possess poorly preserved cortices, indicating that over two thirds of the assemblage is conducive to secure surface-mark identification. Only a single specimen, a cut-marked humerus from a Size Class 3a bovid, was found to preserve definitive hominid surface modifications. Therefore, Table 52 summarizes the raw incidence of tooth marks in the FLK North 5 assemblage. Tooth marks concentrate on limb bones and forelimbs in particular. The limb bones from small carcasses are tooth-marked at higher frequencies than medium carcasses.

Table 52. Tooth-mark frequencies for small (Size Class 1 and 2) and medium (Size Class 3) carcasses at FLK North 5

\begin{tabular}{|lccc|}
\hline Element & Small & Medium & Total \\
\hline Mandible & $0 / 24(0.0)$ & $0 / 8(0.0)$ & $0 / 32(0.0)$ \\
Vertebrae & $3 / 16(18.8)$ & $1 / 27(3.7)$ & $4 / 43(9.3)$ \\
Innominate & $4 / 25(16.0)$ & $3 / 7(42.9)$ & $7 / 32(21.9)$ \\
Ribs & $3 / 23(13.0)$ & $1 / 22(4.5)$ & $4 / 43(9.3)$ \\
Scapula & $2 / 14(14.3)$ & $0 / 12(0.0)$ & $2 / 26(7.7)$ \\
Humerus & $7 / 16(43.8)$ & $2 / 28(7.1)$ & $9 / 44(20.5)$ \\
Radius & $8 / 26(30.8)$ & $1 / 21(4.8)$ & $9 / 47(19.1)$ \\
Ulna & $5 / 10(50.0)$ & $2 / 13(15.4)$ & $7 / 23(30.4)$ \\
Carpals & $0 / 33(0.0)$ & $0 / 17(0.0)$ & $0 / 50(0.0)$ \\
Metacarpal & $14 / 24(58.3)$ & $3 / 19(15.8)$ & $17 / 43(39.5)$ \\
Femur & $4 / 23(17.4)$ & $9 / 30(30.0)$ & $13 / 53(24.5)$ \\
Patella & $0 / 6(0.0)$ & $0 / 2(0.0)$ & $0 / 8(0.0)$ \\
Tibia & $11 / 36(30.6)$ & $6 / 57(10.5)$ & $17 / 92(18.5)$ \\
Tarsals & $2 / 49(4.1)$ & $1 / 28(3.6)$ & $3 / 77(3.9)$ \\
Metatarsal & $10 / 38(26.3)$ & $4 / 22(18.2)$ & $14 / 60(23.3)$ \\
Phalanges & $0 / 127(0.0)$ & $1 / 21(4.8)$ & $1 / 148(0.7)$ \\
Sesamoids & $0 / 35(0.0)$ & $0 * 30(0.0)$ & $0 / 55(0.0)$ \\
Limb bone shaft & $2 / 68(2.9)$ & $9 / 81(11.1)$ & $11 / 149(7.4)$ \\
Total & $75 / 593(12.6)$ & $43 / 435(9.9)$ & $118 / 1,028(11.5)$ \\
\hline
\end{tabular}

Numerator denotes number of marked specimens; denominator denotes total NISP for each skeletal element; percentage is in parentheses 
Given the lack of hominid surface modifications, one would expect tooth-mark frequencies on limb bone midshaft fragments (following Blumenschine's [1988, 1995] bone segment system) to mirror experimental "carnivore-only" scenarios where carnivores enjoyed sole access to flesh and marrow. However, as Figure 115 illustrates midshaft tooth-mark frequencies on small and medium carcasses fall outside the range of variation for these experiments and, for medium carcasses at least, match more closely "hammerstone-to-carnivore" experiments where hyenas ravaged defleshed and demarrowed bones. In the absence of hominid surface modifications and a lack of any other evidence for hominid bone-breaking (see later), it is unlikely, as the midshaft tooth-mark frequencies would initially suggest, that carnivores were ravaging hominid food refuse. However, if felids are considered a primary agent of bone modification at FLK North 5, which seems likely given the evidence presented for Levels 1-4 (see Chapters 8 and 9), the tooth-mark data make more sense. Felids are known to tooth mark limb bones and midshafts in particular at lower frequencies (Selvaggio, 1994; Domínguez-Rodrigo et al., in press) than the hyenas used in previous experimental studies (Blumenschine and Marean, 1993; Blumenchine, 1995; Capaldo, 1997, 1998b) (see Figure 115).
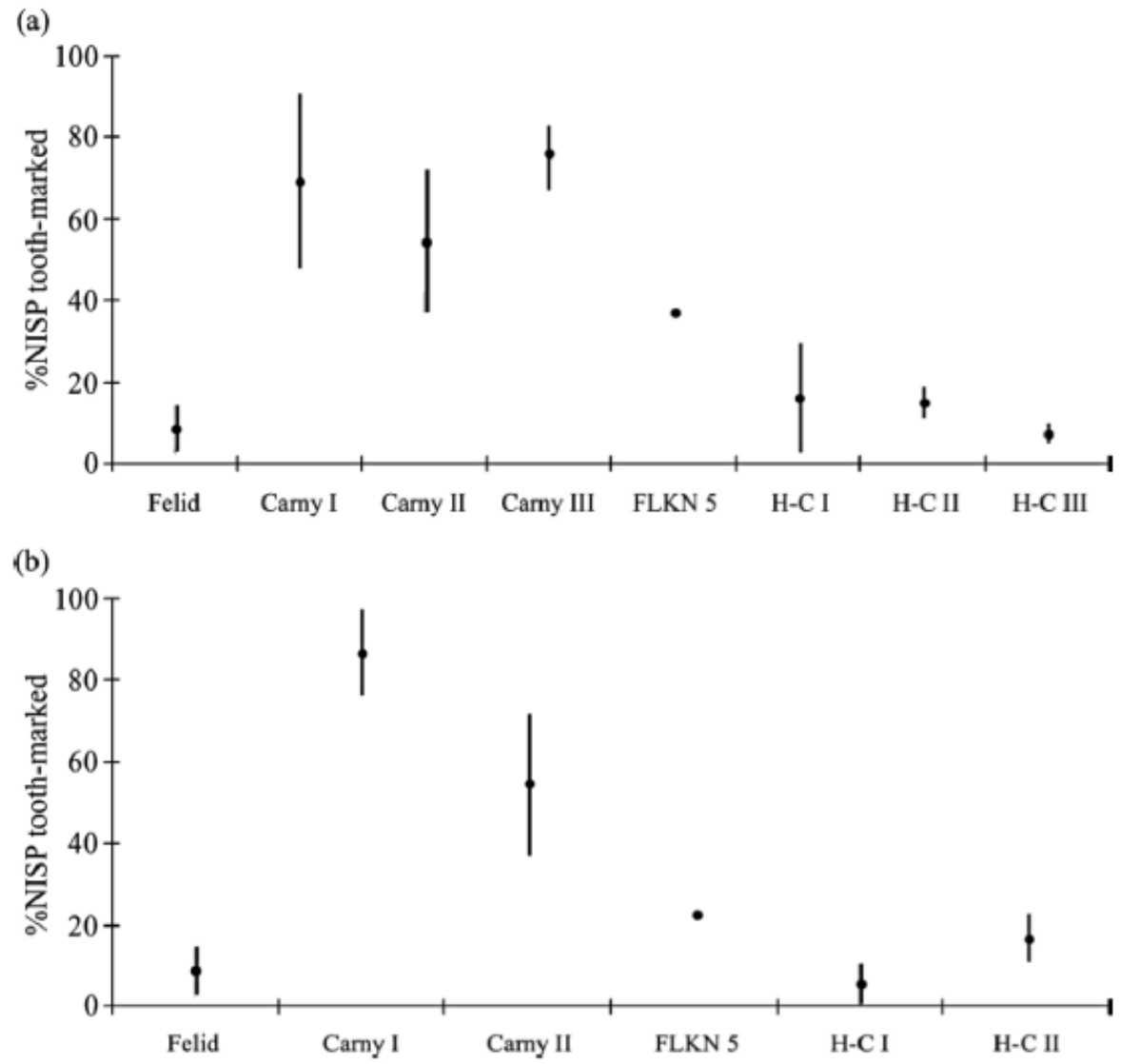

Figure 115. Incidence of tooth-marked midshaft fragments at FLK North 5 for (A) small-sized carcasses and (B) medium-sized carcasses compared to the mean and 95\% confidence intervals for actualistic control assemblages. Only fossil specimens with green breakage and good cortical surface preservation are considered. Abbreviations: Felid, felid-consumed carcasses; Carny, carnivore-only; H-C, hammerstone-to-carnivore. (Data sources: Blumenschine [1995]; Capaldo [1997, 1998a, 1998b]; Marean et al. [2000]; Domínguez-Rodrigo et al. [in press].) Note: The range of variation from Marean's experiments ("Carny III" and "H-C III") are somewhat smaller because confidence intervals were calculated by bootstrapping a single sample (Marean et al., 2000: Table 3). 
Tooth-mark frequencies on epiphyseal and near-epiphyseal fragments at FLK North 5 fall outside the 64-100\% range observed in hyena-ravaged assemblages (Blumenschine, 1995; Capaldo, 1997, 1998b) (Table 53). They are also different from frequencies generated by leopards and cheetahs, which tooth mark these portions at rates of $15.9 \%$ and $16.8 \%$, respectively (Domínguez-Rodrigo et al., in press). The fact that tooth-mark frequencies do not match exactly with any of the published actualistic control samples indicates that FLK North 5 represents a complex palimpsest in which: (1) some felid-modified carcasses were subsequently ravaged by hyenas; (2) some felid-modified carcasses were not ravaged; and (3) some carcasses represent natural deaths that were not processed by carnivores at all.

Table 53. Percentage of epiphyseal, near-epiphyseal, and midshaft specimens bearing tooth marks at FLK North 5

\begin{tabular}{|lcccc|}
\hline & EP & NEP & MSH & Total \\
\hline Small carcasses & & & & \\
NISP & 21 & 8 & 52 & 81 \\
NISP TM & 13 & 2 & 19 & 34 \\
\% & 61.9 & 25.0 & 36.5 & 42.0 \\
Medium carcasses & & & & \\
NISP & 5 & 18 & 36 & 59 \\
NISP TM & 1 & 9 & 8 & 18 \\
$\%$ & 20.0 & 50.0 & 22.2 & 30.5 \\
\hline
\end{tabular}

NISP counts include only those specimens with green breakage and good cortical surface preservation Abbreviations: EP, epiphyseal; NEP, near-epiphyseal; MSH, midshaft

(a)

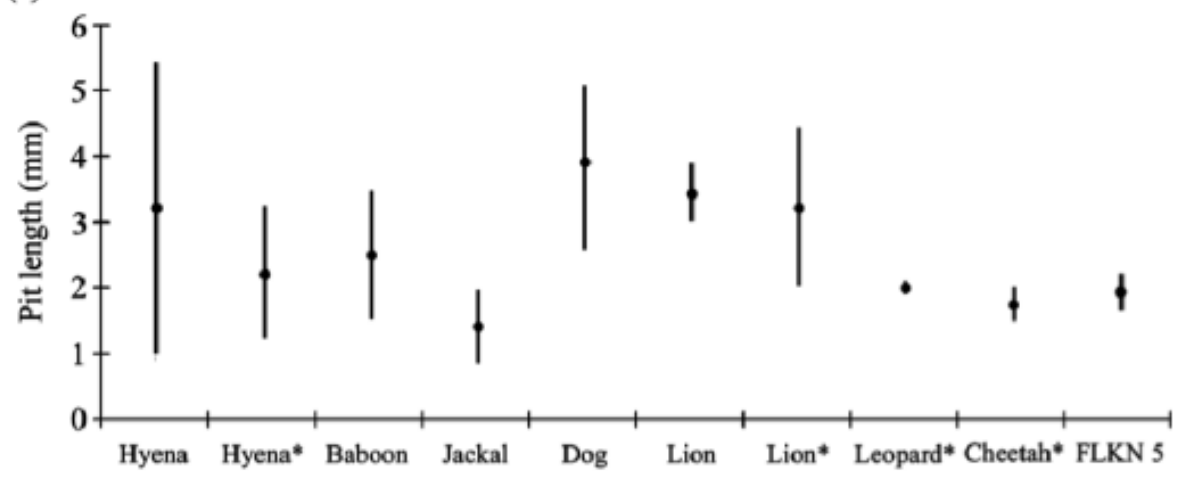

(b)

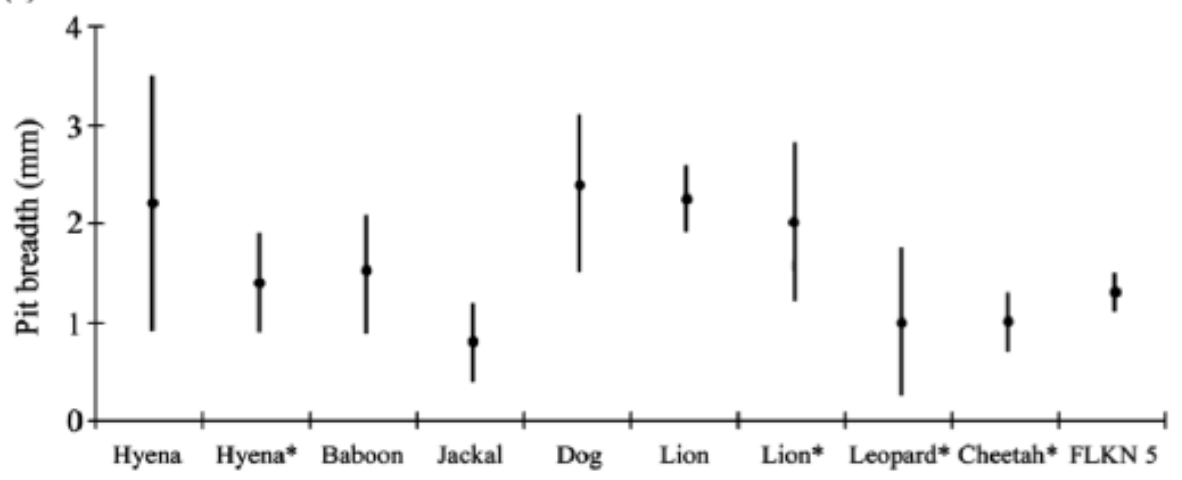

Figure 116. Mean and 95\% confidence intervals for tooth pit (A) lengths and (B) breadths on the limb bone diaphyses of small-sized carcasses at FLK North 5 compared to actualistic samples. (Data indicated with an asterisk $(*)$ are from Selvaggio [1994]; all other modern carnivore data are from Domínguez-Rodrigo and Piqueras [2003].) 
Figure 116 summarizes tooth pit dimensions on small carcasses in the FLK North 5 assemblage. It seems likely that smaller carnivores with less robust dentitions, such as cheetahs and leopards, modified many of the small carcasses at FLK North 5. This is consistent with data presented for the lower levels of FLK North (Chapters 8 and 9) and contrasts with DK, where both small- and medium-sized carcasses were modified by larger carnivores such as lions and hyenas (see Chapter 15). The few tooth pits on medium carcasses $(n=3)$ at FLK North 5 match better with those created by larger carnivores.

\section{BONE BREAKAGE}

Unlike other levels from the FLK North site, FLK North 5 shows relatively high levels of diagenetic breakage, especially for medium carcasses (Figure 117). Complete bones make up a significant proportion of the limb bone MNE (Table 54), and it appears that they were being broken in direct proportion to their nutritional content. The relative proportions of Bunn's (1982) circumference types are similar to Levels 1 and 2 of the FLK North sequence (see Chapter 8) and differ from experimental assemblages with intensive hyena ravaging (Figure 113). The epiphysis-to-shaft fragment ratios for small (0.38) and medium (0.26) carcasses are higher than carnivore-only assemblages where ravaging is very intense (Blumenschine and Marean, 1993; Capaldo, 1998b). These data all suggest a relatively low level of ravaging in the FLK North 5 assemblage.
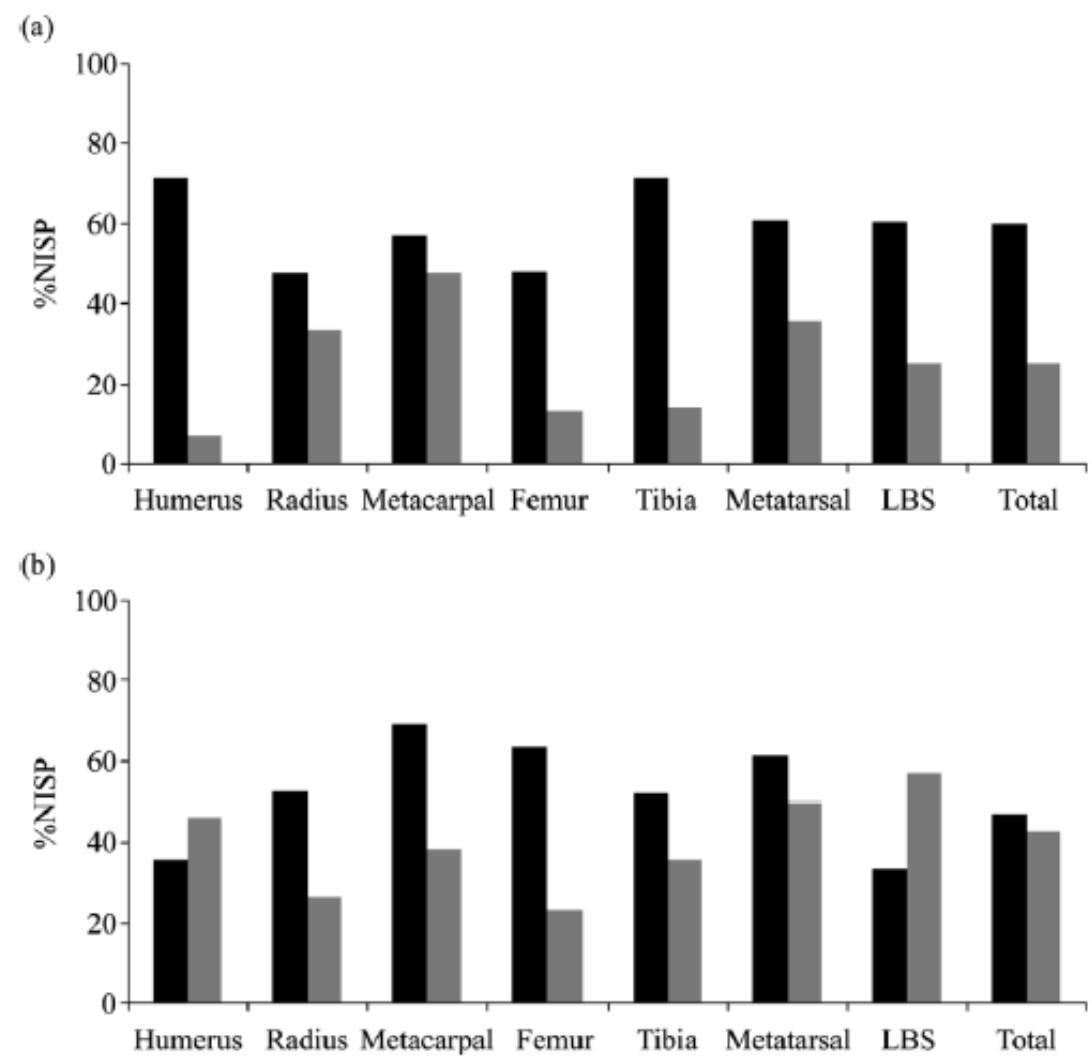

Figure 117. Incidence of green and diagenetic breakage on limb bones from (A) small and (B) medium carcasses at FLK North 5. Percentages may not add to $100 \%$ as specimens with recent breakage are not considered. Abbreviations: LBS, unidentified limb bone shaft. 
Table 54. Frequencies of complete limb bones for small (Size Class 1 and 2) and medium (Size Class 3) carcasses at FLK North 5

\begin{tabular}{|lccc|}
\hline Element & Small & Medium & Total \\
\hline Humerus & $2 / 13(15.4)$ & $0 / 14(0.0)$ & $2 / 27(7.4)$ \\
Radius & $2 / 19(10.5)$ & $1 / 10(10.0)$ & $3 / 29(10.3)$ \\
Metacarpal & $3 / 17(17.6)$ & $6 / 13(46.2)$ & $9 / 30(30.0)$ \\
Femur & $0 / 10(0.0)$ & $0 / 12(0.0)$ & $0 / 22(0.0)$ \\
Tibia & $1 / 23(4.3)$ & $1 / 17(5.9)$ & $2 / 40(5.0)$ \\
Metatarsal & $10 / 20(50.0)$ & $4 / 16(25.0)$ & $14 / 36(38.9)$ \\
Total & $18 / 102(17.6)$ & $12 / 82(14.6)$ & $30 / 184(16.3)$ \\
\hline
\end{tabular}

Numerator denotes number of complete bones; denominator denotes total MNE for each limb bone; percentage is in parentheses

Fracture plane analysis can provide information on the identity of the bone-breaking agent. Although fracture planes from small carcasses overlap with both static (carnivore) and dynamic (hammerstone) experiments (Figure 118), fracture planes from medium-sized carcasses are more consistent with carnivore breakage (Figure 119).

Although only four notches were complete enough to calculate notch breadth:notch depth and scar breadth:notch depth ratios, all fall comfortably within the carnivore range (not pictured). Micronotches, which are characteristic of carnivore-broken assemblages, predominate in FLK North 5 and Incomplete Type $\mathrm{C}$ notches, also common in carnivore-broken assemblages, are abundant among medium-sized carcasses (Figure 120).
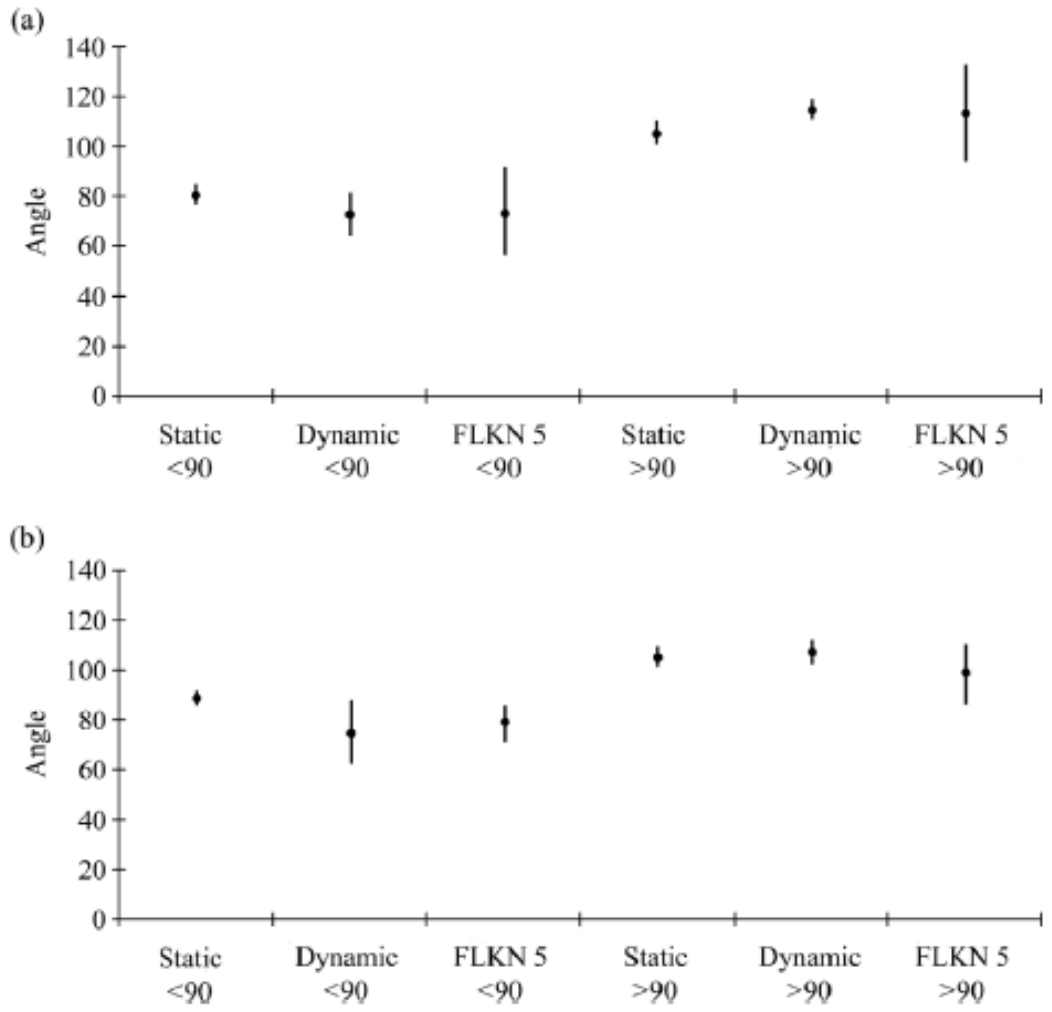

Figure 118. Mean and 95\% confidence intervals of fracture angles from (A) oblique and (B) longitudinal planes on small-sized carcasses at FLK North 5 compared to experimental samples. 
(a)
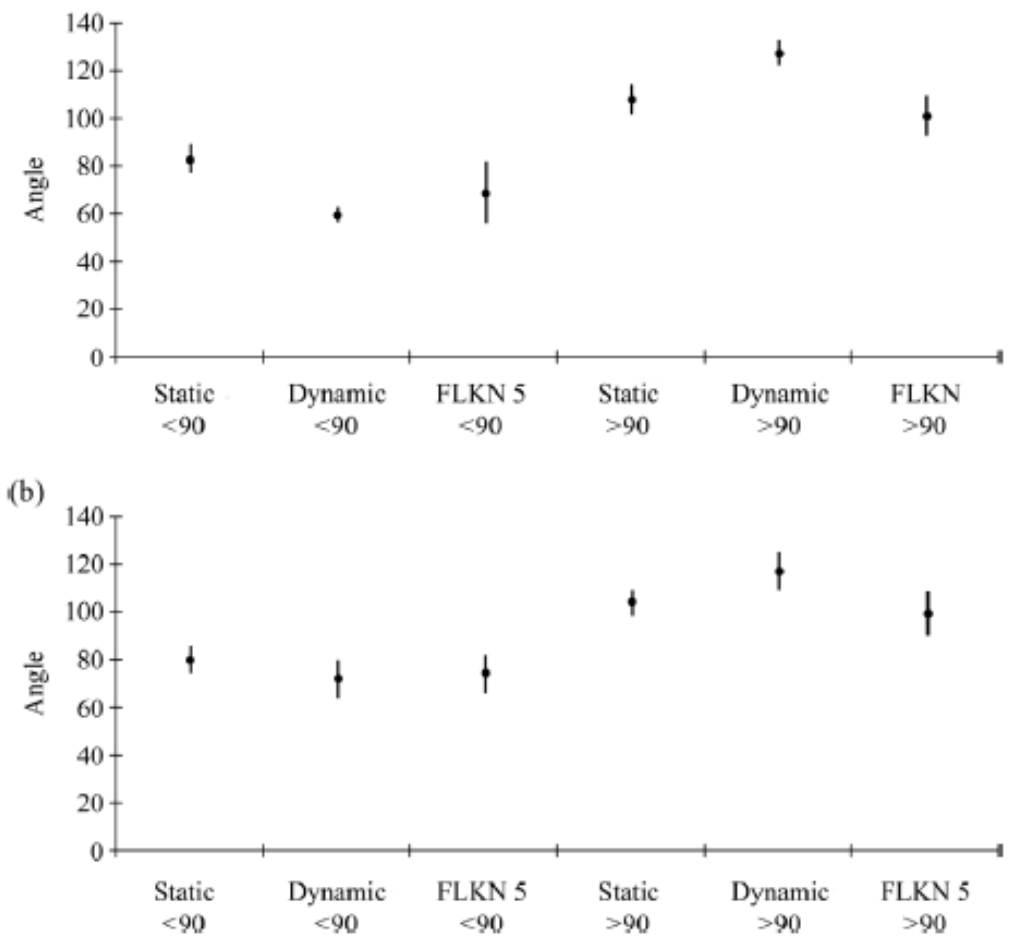

Figure 119. Mean and 95\% confidence intervals of fracture angles from (A) oblique and (B) longitudinal planes on medium-sized carcasses at FLK North 5 compared to experimental samples.

(a)

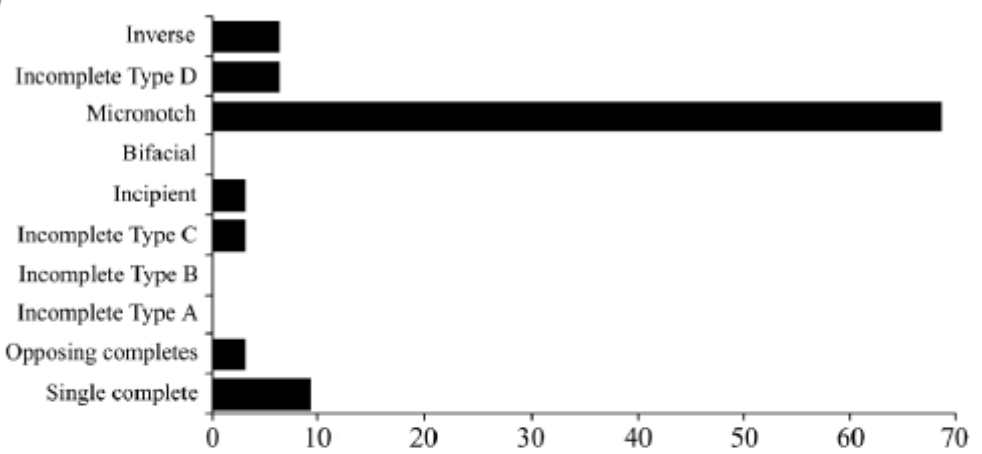

(b)

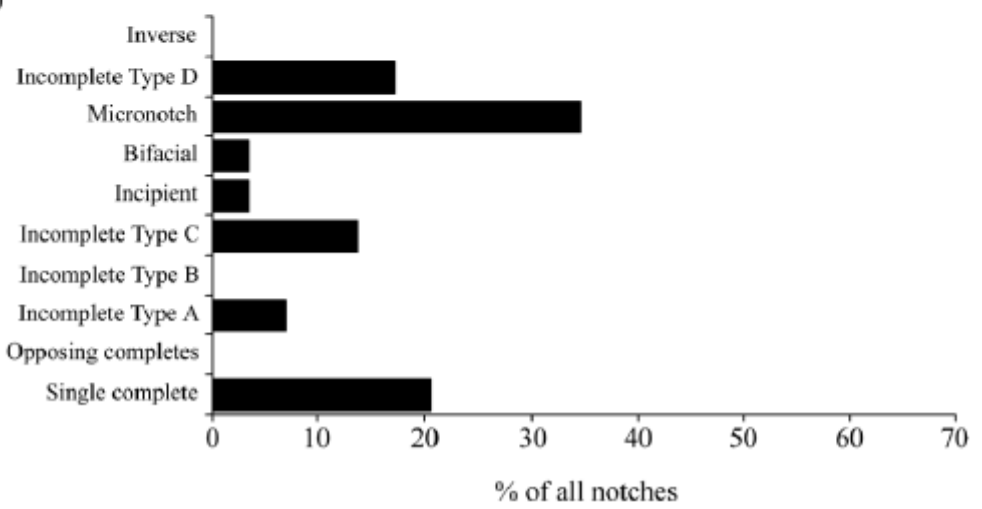

Figure 120. Incidence of notch types (modified from Capaldo and Blumenschine, 1994) from (A) small and (B) medium carcasses in the FLK North 5 assemblage. 


\section{Discussion and Conclusions}

The bone assemblage from FLK North 5 is almost exclusively the result of carnivore activities. The lack of cut marks fits well with the fact that only ten flakes (presumably the main butchering tool of the Oldowan toolkit) occur in the 132-piece lithic assemblage (de la Torre, 2006). Although anvils and lithic pieces with percussion damage are present in the FLK North 5 assemblage (Leakey, 1971; de la Torre, 2006), the absence of percussion marks on bones and any evidence for hominid bone breakage suggests that these tools were used for a purpose other than carcass butchery.

A vast majority of the assemblage derives from just two bovid size classes from two species, $A$. recki (Size Class 1) and $P$. altidens (Size Class 3a). The low diversity of size classes and species strongly suggests some sort of specialized bone collector. A felid is the most likely agent here given the low overall incidence of tooth marks in the FLK North 5 assemblage. Tooth pit dimensions on small carcasses point to a medium-sized felid, and, given their propensity for specializing on two or three different prey species (Scott, 1987; Cavallo, 1998), leopards are a likely candidate. The modification of medium carcasses may be attributable to the larger bodied felid Dinofelis, which appears similar in its strategy of carcass acquisition and processing to leopards (Lewis, 1997).

As noted earlier, a number of factors suggest that the overall intensity of carnivore ravaging at FLK North 5 is low to moderate. The fact that limb bones were broken in proportion to their nutritional content indicates that carnivores were only processing higher yield elements for within-bone nutrients. This suggests further that when carcasses where discovered and processed, group size and/or levels of competition were low. Moreover, the large number of accumulated carcasses coupled with the fact that almost $1.5 \mathrm{ft}$ of Level 5 deposit overlie the similarly thick deposits of Levels 1-4, all of which display high MNIs and felid taphonomic signatures, demonstrates that this area was favorable to felid carcass transport over a long period of time. It is therefore likely that trees were abundant in the vicinity, although within the broader context of a relatively open habitat, as FLK North 5 plots with Levels 1-2 in DomínguezRodrigo and Organista's ravaging stage 2 (see Chapter 11). This is in contrast to DK (Chapter 15) or levels from the FLK North North sequence (Chapters 12-14), which seem to indicate mixed and closed environments, respectively. The FLK North area would have provided hominids ample opportunities to passively scavenge from felid kills. The fact that little to no evidence for hominid carcass exploitation has been documented in these assemblages, including Level 5, indicates that this was not a commonly employed carcass acquisition strategy.

In order to understand the trophic dynamics that created the accumulations of carcasses described in this and previous chapters, it is necessary to know what the background bone scatters were like at Olduvai (some of which were addressed in Chapter 7), and how these scatters compare with the modern savanna ecosystems used as analogs for understanding PlioPleistocene savanna environments. Chapter 11 will provide new data on background bone scatters at Olduvai during Bed I times, and will show that studies of trophic dynamics and competition in modern savannas can be applied to interpret the paleoecological situation in the 
Bed I sites, and therefore to understand the reasons why bones appeared more concentrated in some spots than in others.

\section{References}

Albert, R. M., Bamford, M. K., Cabanes, D. 2006. Taphonomy of phytoliths and macroplants in different soils from Olduvai Gorge (Tanzania) and the application to Plio-Pleistocene palaeoanthropological samples. Quaternary International 148, 78-94.

Alcalá, L. 1994. Macromamíferos neógenos de la fosa de Alfambra-Teruel. Monografías del Instituto de Estudios Tulolenses, Teruel.

Alcántara, V., Barba, R., Barral, J., Crespo, A., Eiriz, A., Falquina, A., Herrero, S., Ibarra, A., Megías, M., Pérez, M., Pérez, V., Rolland, J., Yravedra, J., Vidal, A., DomínguezRodrigo, M. 2006. Determinación de procesos de fractura sobre huesos frescos: un sistema de análisis de los ángulos de los planos de fracturación como discriminador de agentes bióticos. Trabajos de Prehistoria 63(1), 25-38.

Andrews, P., Cook, J. 1985. Natural modifications to bones in a temperate setting. Man 20, 675691.

Andrews, P., Fernández-Jalvo, Y. 1997. Surface modifications of the Sima de los Huesos fossil humans. Journal of Human Evolution 33, 191-217.

Andrews, P., Groves, C. P., Horne, J. F. M. 1975. The ecology of the lower Tana River flood plain. Journal of East African Natural History Society 151, 1-31.

Andrews, P., Humphrey, L. 1999. African Miocene environments and the transtition to early hominines. In Bromage, T., Schrenk, F. (eds.) African Biogeography, Climate Change, and Early Hominid Evolution. Oxford University Press, Oxford, pp. 282-300.

Auffenberg, W. 1981. The fossil turtles of Olduvai Gorge, Tanzania, Africa. Copeia 3, 509-522.

Auguste, P. 1991. Chasse ou charognage au Paléolithique moyen: 1'apport du gisement de Biache-Saint-Vaast (Pas de Calais). Bulletin de la Societé Préhistorique Française, 88, 1167.

Auguste, P. 1995. Chasse ou charognage au Paléolithique moyen: l'apport du gisement de Biache-Saint-Vaast (Pas de Calais). Bulletin de la Societé Préhistorique Française 92, $155-167$.

Bamford, M. K., Albert, R. M., Cabanes, D. 2006. Plio-Pleistocene macroplant fossil remains and phytoliths from lowermost Bed II in the eastern pleolake margin of Olduvai Gorge. Quaternary International 148, 95-112.

Bar-Yosef, O. 1989. Upper Pleistocene cultural stratigraphy in southwest Asia. In Trinkaus, E. (ed.) The Emergence of Modern Humans. Biocultural Adaptations in the Later Pleistocene. Cambridge University Press, Cambridge, pp. 159-180.

Bar-Yosef, O. 1994. The Lower Paleolithic of the Middle East. Journal of World Prehistory 8, 211-265. 
Barba, R., Domínguez-Rodrigo, M. 2005. The taphonomic relevance of the analysis of long limb bone shaft features and their application to implement element identification: study of bone thickness and the morphology of the medullary cavity. Journal of Taphonomy 3 , 111-124.

Barba, R., Domínguez-Rodrigo, M. (in press). Nueva aproximación al estudio de las marcas de corte: definición de "zonas calientes" como indicador de un consumo inicial de las carcasas por parte de los homínidos. Aplicación al conjunto de FLK Zinj (Olduvai). Trabajos de Prehistoria.

Bartram, L. E. 1993. An ethnoarchaeological analysis of Kua San (Bostwana) bone food refuse, Ph.D. Thesis. University of Wisconsin, Madison.

Bartram, L. E., Kroll, E. M., Bunn, H. T. 1991. Variability in camp structure and bone refuse patterning at Kua San hunter-gatherer camps. In Kroll, E., Price, D. (eds.) The Interpretation of Archaeological Spatial Patterning. Plenum Press, New York, pp. 77148.

Bartram, L. E., Marean, C. W. 1999. Explaining the "Klasies Pattern": Kua ethnoarchaeology, the Die Kelders Middle Stone Age archaeofauna, long bone fragmentation and carnivore ravaging. Journal of Archaeological Science 26, 9-29.

Behrensmeyer, A. K. 1978. Taphonomic and ecologic information from bone weathering. Paleobiology 4, 150-162.

Behrensmeyer, A. K. 1983. Patterns of natural bone distribution on recent land surfaces: implications for archaeological site formation. In Clutton-Brock, J., Grigson, C. (eds.) Animals and Archaeology: Hunters and their Prey, B.A.R. International Series, 163, pp. 93-106.

Behrensmeyer, A. K. 2005. Changes over three decades in skeletal part survival and bone modification in the Amboseli ecosystem, southern Kenya. In Pickering, T. R., Toth, N., and Shick, K. (eds.) African Taphonomy: A Tribute to the Career of C.K. Brain. CRAFT Press, Bloomington, Indiana.

Behrensmeyer, A. K., Boaz, D. 1980. The recent bones of Amboseli Park, Kenya, in relation to East African paleoecology. In Behrensmeyer, K. and Hill, A. (eds.) Fossils in the Making. University of Chicago Press, Chicago, pp. 72-92.

Behrensmeyer, A. K., Todd, N. E., Potts, R., McBrinn, G. E. 1997. Late Pliocene faunal turnover in the Turkana Basin, Kenya and Ethiopia. Science 278, 1589-1594.

Bender, M. M. 1971. Variations in the $13 \mathrm{C} / 12 \mathrm{C}$ ratios of plants in relation to the pathway of photosynthetic carbon dioxide fixation. Phytochemistry 10, 1239-1245.

Binford, L. R. 1978. Nunamiut Ethnoarchaeology. Academic Press, New York.

Binford, L. R. 1981. Bones: Ancient Men, Modern Myths. Academic Press, New York.

Binford, L. R. 1984. Faunal Remains from Klasies River Mouth. Academic Press, New York. 
Binford, L. R. 1985. Human ancestors: changing views of their behavior. Journal of Anthropological Archaeology 4, 292-327.

Binford, L. R. 1986. Reply to Bunn and Kroll. Current Anthropology 27, 444- 446.

Binford, L. R. 1988a. Fact and fiction about the Zinjanthropus floor: data, arguments and interpretations. Current Anthropology 29, 123-135.

Binford, L. R. 1988b. The hunting hypothesis, archaeological methods and the past. Yearbook of Physical Anthropology 30, 1-9.

Binford, L. R., Ho, C. K. 1985. Taphonomy at a distance: Zhoukoudian, "the cave-home of Beijing Man"? Current Anthropology 26, 413-439.

Binford, L. R., Mills, L. G. L., Stone, N. M. 1988. Hyena scavenging behavior and its implications for the interpretation of faunal assemblages from FLK 22 (the Zinj floor) at Olduvai Gorge. Journal of Anthropological Archaeology 7, 99-135.

Blasco Sancho, F. 1995. Hombres y Fieras. Estudio Zooarqueológico y Tafonómico del Yacimiento del Paleolítico Medio de la Cueva de Gabasa 1 (Huesca). Monografías de la Universidad de Zaragoza, Zaragoza.

Blumenschine, R. J. 1986. Early Hominid Scavenging Opportunities. Implications of Carcass Availability in the Serengeti and Ngorongoro Ecosystems. B.A.R. International Series, 283, Oxford.

Blumenschine, R. J. 1987. Characteristics of an early hominid scavenging niche. Current Anthropology 28, 383-407.

Blumenschine, R. J. 1988. An experimental model of the timing of hominid and carnivore influence on archaeological bone assemblages. Journal of Archaeological Science 15, 483-502.

Blumenschine, R. J. 1989. A landscape taphonomic model of the scale of prehistoric scavenging opportunities. Journal of Human Evolution 18, 345-371.

Blumenschine, R. J. 1991. Hominid carnivory and foraging strategies, and the socio-economic function of early archaeological sites. Philosophical Transactions of the Royal Society (London) 334, 211-221.

Blumenschine, R. J. 1995. Percussion marks, tooth marks and the experimental determinations of the timing of hominid and carnivore access to long bones at FLK Zinjanthropus, Olduvai Gorge, Tanzania. Journal of Human Evolution 29, 21-51.

Blumenschine, R. J., Bunn, H. T. 1987. On theoretical framework and tests of early hominid meat and marrow adquisition. A reply to Shipman. American Anthropologist 89, $444-$ 448. Blumenschine, R. J., Cavallo, J. A., Capaldo, S. D. 1994. Competition for carcasses and early hominid behavioral ecology: a case study and a conceptual framework. Journal of Human Evolution 27, 197-213.

Blumenschine, R. J., Madrigal, T. C. 1993. Long bone marrow yields of some African ungulates. Journal of Archaeological Science 20, 555-587. 
Blumenschine, R. J., Marean, C. W. 1993. A carnivore's view of archaeological bone assemblages. In Hudson, J. (ed.) From Bones to Behavior: Ethnoarchaeological and Experimental Contributions to the Interpretations of Faunal Remains. Southern Illinois University, Illinois, pp. 271-300.

Blumenschine, R. J., Marean, C. W., Capaldo, S. D. 1996. Blind tests of inter-analyst correspondence and accuracy in the identification of cut marks, percussion marks, and carnivore tooth marks on bone surfaces. Journal of Archaeological Science 23, 493-507.

Blumenschine, R. J., Masao, F. T. 1991. Living sites at Olduvai Gorge, Tanzania? Preliminare lanscape archaeology results in the basal Bed II lake margin zone. Journal of Human Evolution 21, 451-462.

Blumenschine, R. J., Masao, F. 1995. Landscape ecology and hominid land use in the lowermost Bed II Olduvai basin. Proposal submitted to the National Science Foundation.

Blumenschine, R. J., Peters, C. R. 1998. Archaeological predictions for hominid land use in the paleo-Olduvai Basin, Tanzania, during lowermost Bed II times. Journal of Human Evolution 34, 565-607.

Blumenschine, R. J., Peters, C. R., Capaldo, S. D., Andrews, P., Njau, J. K., Pobiner, B. L. in press. Vertebrate taphonomic perspectives on Oldowan hominin land use in the PlioPleistocene Olduvai basin, Tanzania. In Pickering, T., Schick, K., and Toth, N. (eds.) African Taphonomy: A Tribute to the Career of C. K. "Bob" Brain. CRAFT Press (Indiana University), Bloomington, Indiana.

Blumenschine, R.J., Peters, C.R., Masao, F.T., Clarke, R.J., Deino, A.L., Hay, R.L., Swisher III, C.C., Stanistreet, I.G., Ashely, G.M., McHenry, L., J., Sikes, N.E., Van der Merwe, N.J., Tactikos, J.C., Cushing, A.E., Deocampo, D.M., Njau, J.K., Ebert, J.I., 2003. Late Pliocene Homo and hominid land use from Western Olduvai Gorge, Tanzania. Science 299, 1217-1221.

Blumenschine, R. J., Selvaggio, M. M. 1988. Percussion marks on bone surfaces as a new diagnostic of hominid behavior. Nature 333, 763-765.

Blumenschine, R. J., Selvaggio, M. M. 1991. On the marks of marrow bone processing by hammerstones and hyenas: their anatomical patterning and archaeological implications. In Clark, J. D. (ed.) Cultural Beginnings: Approaches to Understanding Early Hominid Life Ways in the African Savanna. R. Habelt, GMBH, Bonn, pp. 17-32.

Bobe, R., Behrensmeyer, A. K. 2004. The expansion of grassland ecosystems in Africa in relation to mammalian evolution and the origin of the genus Homo. Palaeogeography Palaeoclimatology Palaeoecology 207, 399-420.

Bobe, R., Behrensmeyer, A. K., Chapman, R. E. 2002. Faunal change, environmental variability and late Pliocene hominin evolution. Journal of Human Evolution 42, 475-497.

Bodenhorn, B. 2000. It's good to know who your relatives are but we were taught to share with everybody: shares and sharing among Inupiaq households. In Wenzel, G. W., HovelsrudBroad, G., Kishigami, N. (eds.) The Economy of Sharing: Resource Allocation and Modern Hunter-Gatherers. Senri Ethnological Studies 53, pp. 27-60. 
Boesch, C., Boesch, H. 1984. Mental map in wild chimpanzees: an analysis of hammer transports for nut cracking. Primates 25, 160-170.

Bonnefille, R. 1984. Palynological research at Olduvai Gorge. National Geographic Society Research Papers 17, 227-243.

Brain, C. K. 1967. Hottentot food remains and their bearing on the interpretation of fossil bone assemblages. Scientific Papers of the Namib Desert Research Station 32, 1-11.

Brain, C. K. 1969. The probable role of leopards as predators of the Swartkrans Australopithecines. South African Archaeological Bulletin 24, 170-171.

Brain, C. K. 1981. The Hunters or the Hunted? Chicago University Press, Chicago.

Brugal, J. P. 1992. Eco-ethologie des premiers hominid'es en Afrique: Les activités de subsistance. Bulletin et Memoire de la Societé d'Anthropologie de Paris 4, 143-166.

Brugal, J. P., Fosse, P., Guadelli, J. L. 1997. Comparative study of bone assemblages made by recent and Pleistocene hyenids. Paper presented at the Eight Meeting of Working Group 1 on Bone Modification, Hot Springs, South Dakota, USA. September 1993, pp. 158187.

Bunn, H. T. 1981. Archaeological evidence for meat-eating by Plio-Pleistocene hominids from Koobi Fora, Kenya. Nature 291, 574-577.

Bunn, H. T. 1982. Meat-eating and human evolution: studies on the diet and subsistence patterns of Plio-Pleistocene hominids in East Africa, Ph.D. Dissertation. University of California, Berkeley.

Bunn, H. T. 1983a. Evidence on the diet and subsistence patterns of Plio-Pleistocene hominids at Koobi Fora, Kenya, and at Olduvai Gorge, Tanzania. In Clutton-Brock, J., Grigson, C. (eds.) Animals and Archaeology: Hunters and their Prey. B.A.R. International Series, 163, pp. 21-30.

Bunn, H. T. 1983b. Comparative analysis of modern bone assemblages from a San huntergatherer camp in the Kalahari Desert, Bostwana, and froms a spotted hyena den near Nairobi, Kenya. In Clutton-Brock, J., Grigson, C. (eds.) Animals and Archaeology: Hunters and their Prey. B.A.R. International Series, 163, pp. 143-148.

Bunn, H. T. 1986. Patterns on skeletal representation and hominid subsistence activities at Olduvai Gorge, Tanzania, and Koobi Fora, Kenya. Journal of Human Evolution 15, 673690.

Bunn, H. T. 1991. A taphonomic perspective on the archaeology of human origins. Annual Review of Anthopology 20, 433-467.

Bunn, H. T. 1994. Early Pleistocene hominid foraging strategies along the ancestral Omo River at Koobi Fora, Kenya. Journal of Human Evolution 27, 247-266.

Bunn, H. T. 1995. Reply to Tappen. Current Anthropology 36, 250-251. Bunn, H. T. 1996. Reply to Rose and Marshall. Current Anthropology 37, 321-323. 
Bunn, H. T. 2001. Hunting, power scavenging, and butchering by Hadza foragers and by PlioPleistocene Homo. In Stanford, C. B., Bunn, H. T. (eds.) Meat-Eating and Human Evolution. Oxford University Press, Oxford, pp. 199-218.

Bunn, H. T., Ezzo, J. A. 1993. Hunting and scavenging by Plio-Pleistocene hominids: nutritional constraints, archaeological patterns, and behavioural implications. Journal of Archaeological Science 20, 365-398.

Bunn, H. T., Kroll, E. M. 1986. Systematic butchery by Plio-Pleistocene hominids at Olduvai Gorge, Tanzania. Current Anthropology 27, 431-452.

Bunn, H. T., Kroll, E. M. 1988. A reply to Binford. Current Anthropology 29, 123-149.

Bunn, H. T., Kroll, E. M., Bartram, L. E. 1988. Variability in bone assemblage formation from Hadza hunting, scavenging and carcass processing. Journal of Anthropological Archaeology 7, 412-57.

Bunn, H. T., Kroll, E. M., Bartram, L. E. 1991. Bone distribution on a modern East African landscape and its archaeological implications. In Clark, J. D. (ed.) Cultural Beginnings: Approaches to Understanding Early Hominid Life Ways in the African Savanna. U.I.S.P. Monographien Band, 19, 33-54.

Capaldo, S. D. 1995. Inferring hominid and carnivore behavior from dual-patterned archaeological assemblages, Ph.D. Thesis. Rutgers University, New Brunswick.

Capaldo, S. D. 1997. Experimental determinations of carcass processing by Plio-Pleistocene hominids and carnivores at FLK 22 (Zinjanthropus), Olduvai Gorge, Tanzania. Journal of Human Evolution 33, 555-597.

Capaldo, S. D. 1998a. Methods, marks and models for inferring hominid and carnivore behavior. Journal of Human Evolution 35, 323-326.

Capaldo, S. D. 1998b. Simulating the formation of dual-patterned archaeofaunal assemblages with experimental control simples. Journal of Archaeological Science 35, 311-330.

Capaldo, S. D., Blumenschine, R. J. 1994. A quantitative diagnosis of notches made by hammerstone percussion and carnivore gnawing in bovid long bones. American Antiquity 59, 724-748.

Capaldo, S. D., Peters, C. R. 1995. Skeletal inventories from wildebeest drownings at Lakes Masek and Ndutu in the Serengeti ecosystem of Tanzania. Journal of Archaeological Science 22, 385-408.

Cavallo, J. A. 1998. A re-examination of Isaac's central-place foraging hypothesis, Ph.D. Thesis. Rutgers University, New Brunswick.

Cavallo, J. A., Blumenschine, R. J. 1989. Tree-stored leopard kills: expanding the hominid scavenging niche. Journal of Human Evolution 18, 393-399.

Cerling, T. E. 1992. Development of grasslands and savannas in East Africa during the Neogene. Palaeogeography, Palaeoclimatology, Palaeoecology 97, 241-247. 
Cerling, T. E., Bowman, J. R., Oneil, J. R. 1988. An isotopic study of a fluvial lacustrine sequence: the Plio-Pleistocene Koobi Fora sequence, East Africa. Palaeogeography Palaeoclimatology Palaeoecology 63, 335-356.

Cerling, T. E., Harris, J. M., MacFadden, B. J., Leakey, M. G., Quade, J., Eisenmann, V., Ehleringer, J. R., 1997. Global vegetation change through the Miocene/Pliocene boundary. Nature $389,153-158$.

Cerling, T. E., Hay, R. L. 1986. An isotopic study of paleosol carbonates from Olduvai Gorge. Quaternary Research 25, 63-78.

Cerling, T. E., Wang, Y., Quade, J. 1993. Expansion of C4 ecosystems as an indicator of global ecological change in the late Miocene. Nature 361, 344-345.

Child, A. M. 1995. Towards an understanding of the microbial decomposition of archaeological bone in the burial environment. Journal of Archaeological Science 22, 165-174.

Child, A. M., Gillard, R. D., Pollard, A. M. 1993. Microbially-induced promotion of amino acid racemization in bone: isolation of the organisms and detection of their enzymes. Journal of Archaeological Science 20, 159-168.

Clark, J. D. 1970. The Prehistory of Africa. Praeger Publishers, New York

Cleghorn, N., Marean, C. W. 2004. Distinguishing selective transport and in situ attrition: a critical review of analytical approaches. Journal of Taphonomy 2, 43-68.

Cordain, L., Miller, J. B., Eaton, S. B., Mann, N., Holt, H. A., Speth, J. 2000. Plant-animal subsistence ratios and macronutrient energy estimations in worldwide hunter-gatherer diets. American Journal of Clinical Nutrition 71, 681-692.

Creel, S., Creel, N. M. 1996. Limitation of African wild dogs by competition with larger carnivores. Conservation Biology 10, 526-538.

Cushing, A. E. 2002. The landscape zooarchaeology and paleontology of Plio-Pleistocene Olduvai, Tanzania, and their implications for early hominid ecology, Ph.D. Dissertation. Anthropology Department, Rutgers University, New Brunswick.

Cutler, A. H., Behrensmeyer, A. K., Chapman, R. E. 1999. Environmental information in a recent bone assemblage: roles of taphonomic processes and ecological change. In Martin, R., Goldstein, S., Patterson, R. T. (eds.) Fossil Taphonomy: Paleoenvironmental Reconstruction and Environmental Assessment. Palaeogeography, Palaeoclimatology, Palaeoecology 149, 359-372.

Damas, D. 1972. Central Eskimo systems of food sharing. Ethnology 11, 220-240.

Darwin, C. 1871. The Descent of Man. Random House, New York.

DeGusta, D., Beyene Y., Asfaw, B., Gilbert, H., White, T. 2003. The oldest cut-marked bones: Pliocene hominid faunal exploitation at Bouri, Ethiopia. Paper presented at the Paleoanthropological Society Meetings, Tempe, Arizona.

Deocampo, D. M., Blumenschine, R. J., Ashely, G. M. 2002. Wetland diagenesis and traces of early hominids, Olduvai Gorge, Tanzania. Quaternary Research 57, 271-281. 
Domínguez-Rodrigo, 1993. La analítica espacial como herramienta tafonómica: aplicación al entorno de una charca africana. Procesos postdeposicionales y Arqueología espacial 16$17,82-111$.

Domínguez-Rodrigo, M. 1994a. El Origen del Comportamiento Humano. Tipo, Madrid.

Domínguez-Rodrigo, M. 1994b. Dinámica trófica, estrategias de consumo y alteraciones óseas en la sabana africana: resumen de un proyecto de investigación etoarqueológico (19911993). Trabajos de Prehistoria 51, 15-37.

Domínguez-Rodrigo, M. 1996. A landscape study of bone conservation in the Galana and Kulalu (Kenya) ecosystem. Origini 20, 17-38.

Domínguez-Rodrigo, M. 1997a. Meat-eating by early hominids at the FLK 22 Zinjanthropus site, Olduvai Gorge, Tanzania: an experimental approach using cut mark data. Journal of Human Evolution 33, 669-690.

Domínguez-Rodrigo, M. 1997b. A reassessment of the study of cut mark patterns to infer hominid manipulation of fleshed carcasses at the FLK Zinj 22 site, Olduvai Gorge, Tanzania. Trabajos de Prehistoria 54, 29-42.

Domínguez-Rodrigo, M. 1997c. Testing meat-eating in early hominids: analysis of cut-marking processes on defleshed carcasses. Human Evolution 12, 169-182.

Domínguez-Rodrigo, M. 1999a. Flesh availability and bone modification in carcasses consumed by lions. Palaeogeography, Palaeoclimatology and Palaeoecology 149, 373-388.

Domínguez-Rodrigo, M. 1999b. Meat eating and carcass procurement by hominids at the FLK Zinj 22 site, Olduvai Gorge, Tanzania: a new experimental approach to the old huntingversus-scavenging debate. In Ullrich, H. (ed.) Lifestyles and Survival Strategies in Pliocene and Pleistocene Hominids. Edition Archaea, Schwelm, Germany, pp. 89-111.

Domínguez-Rodrigo, M. 2001. A study of carnivore competition in riparian and open habitats of modern savannas and its implications for hominid behavioral modelling. Journal of Human Evolution 40, 77-98.

Domínguez-Rodrigo, M. 2002. Hunting and scavenging by early humans: the state of the debate. Journal of World Prehistory 16, 1-54.

Domínguez-Rodrigo, M. 2003. Bone surface modifications, power scavenging and the "display" model at early archaeological sites: a critical review. Journal of Human Evolution 45, 411-416.

Domínguez-Rodrigo, M. in press. Are all Oldowan sites palimpsests? If so, what can they tell us about hominid carnivory? In Hovers, E., Braun, D. (eds.) Interdiscipinary Approaches to Understanding the Oldowan, Springer, New York.

Domínguez-Rodrigo, M., Barba, R. 2005. A study of cut marks on small-sized carcasses and its application to the study of cut-marked bones from small mammals at the FLK Zinj site. Journal of Taphonomy 2-3, 111-124. 
Domínguez-Rodrigo, M., Barba, R. 2006. New estimates of tooth marks and percussion marks from FLK Zinj, Olduvai Gorge (Tanzania): the carnivore-hominid-carnivore hypothesis falsified. Journal of Human Evolution 50, 170-194.

Domínguez-Rodrigo, M., Egeland, C. P. in press. Hominid-made bone accumulations at Olduvai Bed II archaeological sites? A taphonomic study of HWK EAST 3-5, MNK MAIN, EFHR, FC WEST, SHK and BK.

Domínguez-Rodrigo, M., Egeland, C. P., Pickering, T. R. in press. Models of passive scavenging by early hominids: problems arising from equifinality in carnivore tooth mark frequencies and the extended concept of archaeological palimpsests. In Pickering, T. R., Toth, N., Shick, K. (eds.) African Taphonomy: A Tribute to the Career of C.K. Brain. CRAFT Press, Bloomington, Indiana.

Domínguez-Rodrigo, M., Luque, L., Alcalá, L., de la Torre Sáinz, I., Mora, R., Serrallonga, Medina, V. 2002. The ST Site Complex at Peninj, West Lake Natron, Tanzania: implications for early hominids behavioural models. Journal of Archaeological Science $29,639-665$.

Domínguez-Rodrigo, M., Martí Lezana, R. 1996. Estudio etnoarqueológico de un campamento temporal Ndorobo (Maasai) en Kulalu (Kenia). Trabajos de Prehistoria 53, 131-143.

Domínguez-Rodrigo, M., Pickering, T. R. 2003. Early hominids, hunting and scavenging: a summary of the discussion. Evolutionary Anthropology 12, 275-282.

Domínguez-Rodrigo, M., Pickering, T. R., Semaw, S., Rogers, M. 2005. Cutmarked bones from Pliocene archaeological sites at Gona, Afar, Ethiopia: implications for the function of the world's oldest stone tools. Journal of Human Evolution 48, 109-121.

Domínguez-Rodrigo, M., Piqueras, A. 2003. The use of tooth pits to identify carnivore taxa in tooth-marked archaeofaunas and their relevance to reconstruct hominid carcsass processing behaviours. Journal of Archaeological Science 30, 1385-1391.

Dube, H. C. 2005. An introduction to fungi. Vikas, New Delhi.

Egeland, C. P. 2003. Carcass processing intensity and cutmark creation: an experimental approach. Plains Anthropologist 184, 39-51.

Egeland, C. P., Byerly, R. 2005. Application of return rates to large mammal butchery and transport among hunter-gatherers and its implications for Plio-Pleistocene hominid carcass forgaring and site use. Journal of Taphonomy 3(3), 135-157.

Egeland, C. P., Domínguez-Rodrigo, M and Kerbis J. In preparation. Patterns of tooth-marking and bone breakage in a hyena den from the Maasai Mara (Kenya).

Egeland, C. P., Pickering, T. R., Dominguez-Rodrigo, M., Brain, C. K. 2004. Disentangling stone age palimpsests: determining the functional independent of hominid- and carnivorederived portions of archaeofaunas. Journal of Human Evolution 47, 343-357.

Faith, J. T., Behrensmeyer, A. K. 2006. Changing patterns of carnivore modification in a landscape bone assemblage, Amboseli Park, Kenya. Journal of Archaeological Science $12,1718-1733$. 
Fernández-López, S. 2000. Temas de Tafonomía. Departamento de Paleontología, Facultad de Ciencias Geológicas.

Fernández-Jalvo, Y., Denys, C., Andrews, P., Williams, T, Dauphin, Y., Humphreys, L. 1998. Taphonomy and palaeoecology of Olduvai Bed-I (Pleistocene, Tanzania). Journal of Human Evolution 34, 137-172.

Fisher, J. W. 1995. Bone surface modification in zooarchaeology. Journal of Archaeological Method and Theory 1, 7-65.

Fosse, Ph. 1995. Les herbivores dans les gisements paléolithiques en grotte: Proies des carnivores ou gibier des hommes? Préhistoire et Anthropologie Méditerranéennes 4, 27 39.

Fosse, Ph. 1996. La grotte 1 de Lunel-Viel (Hérault, France): répaire des hyènes du Pléistocéne moyen. Paléo 8, 47-81.

Fosse, Ph., Brugal, J. L., Guadelli, P., Tournepiche, J. F. 1998. Les repaires d'Hyènes des cavernes en Europe occidentale: Présentation et comparaisons de quelques assemblages osseux. Economie Préhistorique: les comportements de subsistance au Paléolithique. XVIIIème Rencontres Internationales d'archéologie et d'Histoire d'Antibes. Éditions APDCA, Sophia Antipolis, 43-61.

Gamble, C. 1986. The Paleolithic Settlement of Europe. Cambridge University Press, Cambridge.

Gamble, C. 1999. The Paleolithic Societies of Europe. Cambridge World Archaeology, Cambridge.

Gargett, R., Hayden, B. 1991. Site structure, kinship and sharing in aboriginal Australia: implications for archaeology. In Kroll, E. M., Price, T. D. (eds.) The Interpretation of Archaeological Spatial Patterning. Plenum Press, New York, pp. 11-32.

Gentry, A. W. and Gentry, A. 1978a. Fossil bovidae (Mammalia) from Olduvai Gorge, Tanzania. London, Bulletin of the British Museum 29, 29: 289-446.

Gentry, A. W. and Gentry, A. 1978b. Fossil bovidae (Mammalia) from Olduvai Gorge, Tanzania. London, Bulletin of the British Museum 29, 30: 1-83.

Gifford-Gonzalez, D. P. 1991. Bones are not enough: analogues, knowledge, and interpretive strategies in zooarcaheology. Journal of Anthropological Archaeology 10, 215-254.

Gould, S. J. 1965. Is uniformitarianism necessary? American Journal of Science 236, 223-228.

Gould, S. J. 1979. Agazziz's marginalia in Lyell's principles, or the perils of uniformity and the ambiguity of heroes. Studies in the History of Biology 3, 119-138.

Gould, R. A. 1980. Living Archaeology. Cambridge University Press, Cambridge.

Grayson, D. K. 1984. Quantitative Zooarchaeology: Topics in the Analysis of Archaeological Faunas. Academic Press, Orlando. 
Greenlee, D. M. 1996. An electron microprobe evaluation of diagenetic alteration in archaeological bone. In Orna, M. V. (ed.) Archaeological Chemistry. American Chemical Society Press, Washington, D.C., pp. 334-354.

Hackett, C. J. 1981. Microscopical focal destruction (tunnels) in exhumed human bones. Medicine, Science and the Law 21, 243-265.

Haneberg, W. C. 1983. A paradigmatic analysis of Darwin's use of uniformitarianism in "The Origin of Species.” The Compass of Sigma Gamma Epsilon 60, 89-94.

Harris, J. W. K., Williamson, P. G., Morris, P. J., de Heinzelin, J., Veniers, J., Helgren, D., Bellomo, R. V., Laden, G., Spang, T. W., Stewart, K., Tappen, M. J. 1990. Archaeology of the Lusso beds. In Boaz, N. T. (ed.) Evolution of the Environments and Hominidae in the African Western Rift Valley, Museum of Natural History, Martinsville, Virginia, pp. $237-272$.

Hay, R. 1963. Stratigraphy of Bed I through IV, Olduvai Gorge, Tanganika. Science 139, 829833.

Hay, R. 1971. Geologic background of Beds I and II. In Leakey, M. D. (ed.) Olduvai Gorge, Vol. 3. Cambridge University Press, London, pp. 9-18.

Hay, R. 1976. The Geology of Olduvai Gorge. Clarendon Press, Oxford.

Hay, R. L., Kyser, T. K. 2001. Chemical sedimentology and paleoenvironmental history of Lake Olduvai, a Pliocene lake in northern Tanzania. Geological Society of America Bulletin $113,1505-1521$.

Haynes, G. 1991. Mammoths, Mastodonts, and Elephants: Biology, Behavior, and the Fossil Record. Cambridge University Press, Cambridge and New York.

Hedges, R. E. M., Millard, A. R., Pike, A. W. G. 1995. Measurements and relationships of diagenetic alteration of bone from three archaeological sites. Journal of Archaeological Science 22, 201-209.

de Heinzelin, J., Clark, J. D., White, T., Hart, W., Renne, P., WoldeGabriel, G., Beyene, Y., Vrba, E. 1999. Environment and behavior of 2.5-million-yearold Bouri hominids. Science 284, 625-629.

Hill, A. 1975. Taphonomy of contemporary and late Cenozoic East African vertebrates, Ph.D. Dissertation. University of London, London.

Hill, A. 1979a. Butchery and natural dissarticulation. American Antiquity 44, 739-744.

Hill, A. 1979b. Disarticulation and scattering of mammal skeletons. Paleobiology 5, 261-274.

Hill, A. 1980. Early postmortem damage to the remains of some contemporary east african mammals. In Behrensmeyer, A. K.and Hill, A. (eds.) Fossils in the Making. University of Chicago Press, Chicago, pp. 131-152.

Hill, A., Behrensmeyer, A. K. 1984. Dissarticulation patterns of some modern East African mammals. Paleobiology 10, 366-376. 
Isaac, G. L. 1976. The activities of early african hominids. In Isaac, Mc Cown (eds.) Human Origins. Benjamin, Menlo Park, California, pp. 483-514.

Isaac, G. L. 1978. The food-sharing behavior of protohuman hominids. Scientific American 238, 90-108.

Isaac, G. L. 1983. Bones in contention: competing explanations for the juxtaposition of Early Pleistocene artifacts and faunal remains. In Clutton-Brock, J. and Grigson, C. (eds.) Animals and Archaeology 1. Hunters and Their Prey. B.A.R. International Series, 163, Oxford, pp. 3-19.

Isaac, G. L. 1984. The archaeology of human origins: studies of Lower Pleistocene in East Africa, 1971-1981. Advances in World Archaeology 3, 1-87.

Isaac, G. 1997. Plio-Pleistocene archaeology. Koobi Fora Research Project. Volumen V. Cambridge University Press, Cambridge.

Isaac, G. L., Crader, D. C. 1981. To what extent were early hominids carnivorous? An archaeological perspective. In Harding, R. S. O., Teleki, G. (eds.) Omnivorous Primates. Columbia University Press, New York, pp. 37-103.

Isaac, G. L. and Marshall, F. 1981. Small is informative: the application of the study of minisites and least-effort criteria in the interpretation of the early Pleistocene archaeological record at Koobi Fora. In (Clark, J. D. and Isaac, G. L., eds.) Las industrias mas antiguas. Maxico, Comision VI, Xth Congress UISPP, pp. 101-119.

Jackes, M., Sherburne, R., Lubell, D., Barker, C., Wayman, M. 2001. Destruction of the microstructure in archaeological bone: a case study from Portugal. International Journal of Osteoarchaeology 11(6), 387-399.

Jacobs, B. F., Kingston, J. D., Jacobs, L. L. 1999. The origin of grass-dominated ecosystems. Annals of the Missouri Botanical Garden 86, 590-643.

Jaeger, J. J. 1976. Les rongeurs (Mammalia, Rodentia) du Pleistocene inferieur d'Olduvai Bed I (Tanzanie), lere partie: Les Murides. In Savage, R. J. G., Coryndon, S. C. (eds.) Fossil Vertebrates of Africa, Vol. 4. Academic Press, London, pp. 57-120.

Kappelman, J. 1984. Plio-Pleisocene environments of Bed I and lower Bed II, Olduvai Gorge, Tanzania. Palaeogeography, Palaeoclimatology, Palaeoecology 48, 171-196.

Kappelman, J. 1986. Plio-Pleistocene marine-continental correlation using habitat indicators from Olduvai Gorge, Tanzania. Quaternary Research 25, 141-149.

Kappelman, J., Plummer, T., Bishop, L., Duncan, A., Appleton, S. 1997. Bvids as indicators of Plio-Pleistocene environments in East Africa. Journal of Human Evolution 32, 229-256.

Keeley, L. H., Toth, N. 1981. Microwear polishes on early stone tools from Koobi Fora, Kenya. Nature 293, 464-465.

Kerbis, J. 1990. The roles of leopards, hyena and porcupines in ungulate carcass dispersal: implications for paleoanthropology, Ph.D. Dissertation. Department of Anthropology, University of Chicago, Chicago. 
Kingston, J. D., Marino, B. D., Hill, A. 1994. Isotopic evidence for Neogene hominid paleoenvironments in the Kenya Rift Valley. Science 264, 955-959.

Klein, R. G. 1982a. Age (mortality) profiles as a means of distinguishing hunted species from scavenged ones in Stone Age archaeological sites. Paleobiology 8, 151-158.

Klein, R. G. 1982b. Patterns of ungulate mortality and ungulate mortality profiles from Langebaanweg (Early Pliocene) and Elandsfontain (Middle Pleistocene), South-western Cape Province, South Africa. Annals of the South African Museum 90, 49-94.

Klein, R. G. 1986. Reply to Bunn and Kroll (1986). Systematic butchery by Plio-Pleistocene hominids at Olduvai Gorge, Tanzania. Current Anthropology 27, 431-452.

Klein, R. G., Cruz-Uribe, K. 1984. The Analysis of Animal Bones from Archaeological Sites. University of Chicago Press, Chicago.

Kruuk, H. 1972. The Spotted Hyena. University of Chicago Press, Chicago.

Kruuk, H., Turner, M. 1967. Comparative notes on predation by lion, leopard, cheetah and wild dog in the Serengeti area, East Africa. Mammalia 31, 1-27.

Kuhn, T. S. 1962. The Structure of Scientific Revolutions. Princeton University Press, Princeton.

Lakatos, I. 1978. The Methodology of Scientific Research Programmes. Cambridge University Press, Cambridge.

Lam, Y. M. 1992. Variability in the behaviour of spotted hyaenas as taphonomic agents. Journal of Archaeological Science 19, 398-406.

Lam, Y. M., Chen, X., Pearson, O. M. 1999. Intertaxonomic variability in patterns of bone density and the differential representation of bovid, cervid and equid elements in the archaeological record. American Antiquity 64, 343-362.

Leakey, L. 1959. A new fossil skull from Olduvai. Nature 184, 491-3.

Leakey, M. 1971. Olduvai Gorge, Vol. 3. Excavations in Bed I and II, 1960-1963. Cambridge University Press, Cambridge.

Levin, N. E., Quade, J., Simpson, S. W., Semaw, S., Rogers, M. J. 2004. Isotopic evidence for Plio-Pleistocene environmental change at Gona, Ethiopia. Earth and Planetary Science Letters 219, 93-110.

Lewis, M. E. 1997. Carnivoran paleoguilds of Africa: implications for hominid food procurement strategies. Journal of Human Evolution 32, 257-288.

Ludwig, B. V. 1999. A technological reassessment of East African Plio-Pleistocene lithic artifact assemblages, Unpublished Ph.D. University of Rutgers, New Brunswick, p. 432.

Lupo, K. D. 1994. Butchering marks and carcass acquisition strategies: distinguishing hunting from scavenging in archaeological contexts. Journal of Archaeological Science 21, 827837. 
Lupo, K. D. 1998. Experimentally derived extraction rates for marrow: implications for body part exploitation strategies of Plio-Pleistocene hominid scavengers. Journal of Archaeological Science 21, 827-837.

Lupo, K. D., O'Connell, J. F. 2002. Cut and tooth mark distributions on large animal bones: ethnoarchaeological data from the Hadza and their implications for current ideas about early human carnivory. Journal of Archaeological Science 29, 85-109.

Lyman, R. L. 1984. Bone density and differential survivorship in fossil classes. Journal of Anthropological Archaeology 3, 259-299.

Lyman, R. L. 1985. Bone frequencies: differential transport, in situ destruction and the MGUI. Journal of Archaeological Science 12, 221-236.

Lyman, R. 1994. Vertebrate Taphonomy. Cambridge University Press, Cambridge.

Lyman, R. 2004. The concept of equifinality in taphonomy. Journal of Taphonomy 2, 15-26.

Lyman, R. 2006. Analyzing cut marks: lessons from artiodactyl remains in the northwestern United States. Journal of Archaeological Science 32, 1722-1732.

Lyman, R., Fox, J. 1989. A critical evaluation of bone weathering as an indication of bone assemblage formation. Journal of Archaeological Science 16, 293-317.

Maguire, J. M., Pemberton, D., Collett, M. H. 1980. The Makapansgat limeworks grey breccia: hominids, hyaenas, hystricids or hillwash? Paleontologia Africana 23, 75-98.

Manega, P. C. 1993. Geochronology, geochemistry and isotopic study of the Plio-Pleistocene hominid sites and the Ngorongoro Volcanic highland in Northern Tanzania, Ph.D. Dissertation. University of Colorado, Boulder.

Marchiafava, V., Bonucci, E., Ascenzi, A. 1974. Fungal osteoclasia: a model of dead bone resorption. Calcified Tissue Research 14, 195-210.

Marean C. W. 1989. Sabertooth cats and their relevance for early hominid diet and evolution. Journal of Human Evolution 18, 559-582.

Marean, C. W. 1998. A critique of the evidence for scavenging by Neandertal and early modern humans: new data from Kobeh Cave (Zagros, mountains, Iran) and Die Kelders Cave 1 Layer 10 (South Africa). Journal of Human Evolution 35, 111-136.

Marean, C. W., Abe, Y., Frey, C. J., Randall, R. C. 2000. Zooarchaeological and taphonomic analysis of the Die Kelders Cave 1 layers 10 and 11 Middle Stone Age larger mammal fauna. Journal of Human Evolution 38, 197-233.

Marean, C. W., Cleghorn, N. 2003. Large mammal skeletal element transport: applying foraging theory in a complex taphonomic system. Journal of Taphonomy 1, 15-42.

Marean, C. W., Domínguez-Rodrigo, M., Pickering, T. R. 2004. Skeletal element equifinality in zooarchaeology begins with method: the evolution and status of the "shaft critique". Journal of Taphonomy 2, 69-98. 
Marean, C. W., Ehrhardt, C. L. 1995. Paleoanthropological and paleoecological implications of the taphonomy of a sabertooth's den. Journal of Human Evolution 29, 515-547.

Marean, C. W., Frey, C. 1997. Animal bones from caves to cities: reverse utility curves as methodological artifacts. American Antiquity 62, 698-716.

Marean, C. W., Kim, S. Y. 1998. Mousterian large mammal remains from Kobeh cave. Current Anthropology 39, 79-113.

Marean, C. W., Spencer, L. M. 1991. Impact of carnivore ravaging of bone in archaeological assemblages. Journal of Archaeological Science 18, 677-694.

Marean, C. W., Spencer, L. M., Blumenschine, R. J., Capaldo, S. 1992. Captive hyaena bone choice and destruction, the Schlepp effect and Olduvai archaeofaunas. Journal of Archaeological Science 19, 101-121.

Marlowe, F. W. 2005. Hunter-gatherers and human evolution. Evolutionary Anthropology 14(2), 54-67.

Marra, A. C., Villa, P., Beauval, L, Bonfiglio, L., Goldberg, P. 2004. Same predator, variable prey: taphonomy of two Upper Pleistocene hyena dens in Sicily and SW France. Revue de Paleobiologie 23(2), 787-801.

Marshall, F. 1986. Implications of bone modification in a Neolithic faunal assemblage for the study of early hominid butchery and subsistence practices. Journal of Human Evolution $15,661-672$.

Marshall, F. 1994. Food sharing and body part representation in Okiek faunal assemblages. Journal of Archaeological Science 21, 65-77.

Martínez, J. 1998. El modo de vida Neandertal: Una reflexión en torno a la ambigüedad en la interpretación de la subsistencia durante el Paleolítico Medio cantábrico, Tesis Doctoral. Facultad de Filosofia y Letras, Universidad Autónoma de Barcelona, Barcelona.

McClanahan, T. R., Young, T. P. 1996. East African ecosystems and their conservation. Oxford University Press, New York.

deMenocal, P. B. 1995. Plio-Pleistocene African climate. Science 270, 53-59.

deMenocal, P. B. 2004. African climate change and faunal evolution during the PliocenePleistocene. Earth and Planetary Science Letters 220, 3-24.

Merrick, H. V., Merrick, J. P. S. 1976. Archaeological ocurrences of earlier Pleistocene ages from the Shungura Formation. In Coppens, Y., Howell, F. C., Isaac, G. L., Leakey, R. E. F. (eds.) Earliest man and environments in the Lake Rudolf Basin. Chicago University Press, Chicago, pp. 574-584.

Metcalfe, D. 1989. A general cost/benefits model of the trade-off between transport and field processing. Papers presented at the 54th Annual Meeting of the Society for American Archaeology, Atlanta.

Metcalfe, D., Barlow, K. R. 1992. A model for exploring the optimal trade-off between field processing and transport. American Anthropologist 94, 340-356. 
Monahan, C. M. 1996. New zooarchaeological data from Bed II, Olduvai Gorge, Tanzania: implications for hominid behavior in the Early pleistocene. Journal of Human Evolution 31, 93-128.

Monahan, C. M. 1998. The Hadza carcass transport debate revisited and its archaeological implications. Journal of Archaeological Science 25, 405-524.

Mora, R., de la Torre, I. 2005. Percussion tools in Olduvai Bed I and II (Tanzania): implications for early human activities. Journal of Anthropological Archaeology 24, 179-192.

Nilssen, P. J. 2000. An actualistic butchery study in South Africa and its implications for reconstructing hominid strategies of carcass acquisition and butchery in the Upper Pleistocene and Plio-Pleistocene, Ph.D. Dissertation. University of Cape Town, Cape Town, South Africa.

Njau, J. and Blumenschine, R. 2006. A diagnosis of crocodile feeding traces on larger mammal bone with fossil examples from the Plio-Pleistocene Olduvai Basin, Tanzania. Journal of Human Evolution 50, 142-162.

Nooter, G. 1975. Leadership and headship: changing patterns in an East Greenland hunting community. Mededelingen van het Rijksmuseum voor Volkenkunde 20.

O’Connell, J. F. 1997. On Plio-Pleistocene archaeological sites and central places. Current Anthropology 38, 86-88.

O’Connell, J. F., Hawkes, K., Blurton Jones, N. 1988. Hadza hunting, butchering and bone transport and their archaeological implications. Journal of Anthropological Research 44, $113-161$.

O’Connell, J. F., Hawkes, K., Blurton Jones, N. 1990. Reanalysis of large mammal body part transport among the Hadza. Journal of Archaeological Science 17, 301-316.

O’Connell, J. F., Hawkes, K., Blurton Jones, N. 1991. Distribution of refuse-producing activities at Hadza residential base camps: implications for analysis of archaeological site structure. In Kroll, E., Price, T. D. (eds.) The Interpretation of Archaeological Spatial Patterning. Plenum Press, Nueva York, pp. 61-76.

O’Connell, J. F., Hawkes, K., Blurton Jones, N. 1992. Patterns in the distribution, site structure and assemblage composition of Hadza kill-butchering sites. Journal of Archaeological Science 19, 319-345.

O’Connell, J. F., Hawkes, K., Lupo. K. D., Blurton Jones, N. 2002. Male strategies and PlioPleistocene archaeology. Journal of Human Evolution 43, 831-872.

O’Connell, J., Hawkes, K., Lupo, K., Blurton-Jones, N. G. 2003. Another reply to DomínguezRodrigo. Journal of Human Evolution 45, 417-419.

Oliver, J. S. 1994. Estimates of hominid and carnivore involvement in the FLK Zinjanthropus fossil assemblage: some socioecological implications. Journal of Human Evolution 27, 267-294. 
Pales, L., Lambert, C. 1971. Mammiferes du Quaternaire. Les membres (herbivores). Centre National de Recherche Scientifique, Paris VII.

Perez-Ripoll, M. 1992. Marcas de carnicería, fracturas intencionadas y mordeduras de carnivoros en huesos prehistoricos del mediterraneo español. Diputacion provincial de Alicante, Alicante.

Perkins, D., Daly, P. 1968. A hunter's village in Neolithic Turkey. Scientific American 219, 96106.

Peters, C. R., Blumenschine, R. J. 1995. Landscape perspectives on possible land use patterns for Early Pleistocene hominids in the Olduvai Basin, Tanzania. Journal of Human Evolution 29, 321-362.

Petraglia, M.D. and Potts, R. 1994. Water flow and the formation of Early Pleistocene artefact sites in Olduvai Gorge, Tanzania. Journal of Anthropological Archaeology 13, 228-254.

Pickering, T. R. 2002. Reconsideration of criteria for differentiating faunal assemblages accumulated by hyaenas and hominids. International Journal of Osteoarchaeology 12, $127-141$.

Pickering, T. R., Domínguez-Rodrigo, M. 2005. The acquisition and use of large mammal carcasses by Oldowan hominins in Eastern and Southern Africa: a selected review and assessment. In Toth, N., Schick, K. (eds.) The Oldowan: Studies into the Origins of Human Technology. Stone Age Institute Press, Bloomington, pp. 113-128.

Pickering, T. R., Domínguez-Rodrigo, M., Egeland, C., Brain, C. K. 2004. New data and ideas on the foraging behavior of Early Stone Age hominids at Swartkrans cave. South African Journal of Science 100, 215-220.

Pickering, T. R., Domínguez-Rodrigo, M., Egeland, C. P., Brain, C. K. 2005a. The contribution of limb bone fracture patterns to reconstructing early hominid behavior at Swartkrans Cave (South Africa): Archaeological application of a new analytical method. International Journal of Osteoarchaeology 15, 247-260.

Pickering, T. R., Domínguez-Rodrigo, M., Egeland, C., Brain, C. K., Kuman, K. 2005b. Carcass foraging by early hominids at Swartkrans Cave (South Africa): A new investigation of the zooarchaeology and taphonomy of member 3. In Pickering, T. R., Toth, N., Shick, K. (eds.) African Taphonomy: A Tribute to the Career of C.K. Brain. CRAFT Press, Bloomington, Indiana (en prensa).

Pickering, T. R., Egeland, C. P. 2006. Experimental pattern of hammerstone percussion damage on bones: implications for inferences of carcass processing by humans. Journal of Archaeological Science 33, 459-469.

Pickering, T. R., Marean, C. W., Domínguez-Rodrigo, M. 2003. Importance of limb bone shaft fragments in zooarchaeology: a response to "On in situ attrition and vertebrate body part profiles” (2002) by M. C. Stiner. Journal of Archaeological Science 30, 1469-1482.

Pickering, T. R., Wallis, J. 1997. Bone modifications resulting from captive chimpanzee mastication: implication for the interpretation of Pliocene archaeological faunas. Journal of Archaeological Science 24, 1115-1127. 
Piepenbrink, H. 1984. Examples of signs of biogenic decomposition in bones long buried. Anthropologischer Anzeiger 42, 241-251.

Plummer, T. W. 2004. Flaked stones and old bones: biological and cultural evolution at the dawn of technology. Yearbook of Physical Anthropology 47, 118-164.

Plummer, T., Bishop, L. 1994. Hominid paleoecology at Olduvai Gorge, Tanzania, as indicated by bovid remains. Journal of Human Evolution 27, 47-75.

Potts, R. 1982. Lower Pleistocenes site formation and hominid activities at Olduvai Gorge, Tanzania, Ph.D. Dissertation. Harvard University, Massachussets.

Potts, R. 1983. Foraging for faunal resources by early hominids at Olduvai Gorge, Tanzania. In (Clutton-Brock, J., Grigson, C., eds.) Animals and ArchaeologyI: Hunters and their Prey. British Arcnaeological Reports International Series 163, Oxford, pp. 51-62.

Potts, R. 1984. Hominid hunters? Problems of identifying the earliest hunter/gatherers. In Foley, R. (ed.) Hominid Evolution and Community Ecology. Academic Press, London, pp. 129166.

Potts, R. 1986. Temporal span of bone accumulations at Olduvai Gorge and implications for early hominid foraging behavior. Paleobiology 12, 25-31.

Potts, R. 1988. Early Hominid Activities at Olduvai. Aldine, New York.

Potts, R. 1991. Why the Oldowan? Plio-Pleistocene tool making and the transport of resources. Journal of Anthropological Research 47, 53-176.

Potts, R. 1993. Archeological interpretations of early hominid behavior and ecology. In Rasmussen, D. T. (ed.) The Origin and Evolution of Humans and Humanness. Jones and Bartlett, Boston. pp. 49-74.

Potts, R. 1994. Variables versus models of early Pleistocene hominid land use. Journal of Human Evolution 27, 7-24.

Potts, R., Shipman, P. 1981. Cutmarks made by stone tools from Olduvai Gorge, Tanzania. Nature 291, 577-580.

Pumarejo, P., Cabrera, V. 1992. Huellas de descarnado en el Paleolítico Superior: la cueva de El Castillo (Cantabria). Espacio, Tiempo y Forma, Serie I, Arqueología y Prehistoria 5, $139-152$.

Roche, H., Delagnes, A., Brugal, J.-P., Feibel, C., Kibunjia, M., Mourre, V., Texier, P. J. 1999. Early hominid stone tool production and technical skill 2.34 Myr ago in West Turkana, Kenya. Nature 399, 57-60.

Rose, L., Marshall, F. 1996. Meat eating, hominid sociality, and home bases revisited. Current Anthropology 37, 307-338.

Rudwick, M. J. S. 1971. Uniformity and progression: reflections on the structure of geological theory in the age of Lyell. In Roller, D. (ed.) Perspectives in the History of Science and Technology. University of Oklahoma Press, Norman, pp. 209-227. 
Ruiter, D. J., Berger, L. R. 2000. Leopards as taphonomic agents in dolomitic caves-implications for bone accumulations in the hominid-bearing deposits of South Africa. Journal of Archaeological Science 27, 665-684.

Schaller, G. B. 1972. The Serengeti Lion. University of Chicago Press, Chicago.

Schick, K. D. 1984. Processes of Paleolithic site formation: an experimental study. Berkeley, University of California, $\mathrm{Ph}$. D. dissertation.

Schick, K. D. 1987. Modeling the formation of early stone age artifact concentrations. Journal of Human Evolution 16, 789-808.

Schick, K., Toth, N. 1993. Making Silent Stones Speak. Simon \& Schuster, New York.

Scott, J. 1985. The Leopard's Tale. Elm Tree Books, London.

Scott, J. 1987. The leopard's tale. Elm Tree Books, Nairobi.

Seilacher, A., Reif, W. E., Westphal, F. 1985. Sedimentological, ecological and temporal patterns of fossil Lagerstätten. Philosophical Transactions of the Royal Society (London) $311,5-23$.

Selvaggio, M. M. 1994. Identifying the timing and sequence of hominid and carnivore involvement with Plio-Pleistocene bone assemblages from carnivore tooth marks and stone-tool butchery marks on bone surfaces, Ph.D. Dissertation. Rutgers University, New Brunswick.

Selvaggio, M. M., Wilder, J. 2001. Identifying the involvement of multiple carnivore taxa with archaeological bone assemblages. Journal of Archaeological Science 28, 465-470.

Semaw, S., Renne, P., Harris, J. W. K., Feibel, C. S., Bernor, R. L., Fesseha N., Mowbray, K. 1997. 2.5-million-year-old stone tools from Gona, Ethiopia. Nature 385, 333-336.

Shackleton, N. J. 1995. New data on the evolution of Pliocene climatic variability. In Vrba, E. (ed.) Paleoclimate and Evolution with Emphasis on Human Origins. Yale University Press, New Haven, pp. 242-248.

Sharmin, S., Kishi, F., Sano, A., Kamei, K., Nishimura, K., Miyaji, M. 2003. Direct invasion of bones by highly pathogenic fungi in an in vitro model and its ecological significance. Japanese Journal of Medical Mycology 44, 17-23.

Shea, J. H. 1982. Twelve fallacies of uniformitarianism. Geology 10, 455-460.

Shipman, P. 1975. Implications of drought for vertebrate fossil assemblages. Nature 257, 67668.

Shipman, P. 1983. Early hominids lifestyle: hunting and gathering or foraging and scavenging. In Clutton-Brock, J., Grigson, C. (eds.) Animals and Archaeology, Vol. 1: Hunters and their Prey. BAR, 163, London, pp. 31-49.

Shipman, P. 1986. Scavenging or hunting in early hominids: theoretical framework and tests. American Anthropologist 88, 27-43. 
Shipman, P., Fisher, D. C., Rose, J. 1984. Mastodon butchery: microscopic evidence of carcass processing and bone tool use. Paleobiology 10, 358-365.

Shipman, P., Harris, J. M. 1988. Habitat preference and paleoecology of Australopithecus boisei in eastern Africa. In Gribe, F. E. (ed.) Evolutionary History of the "Robust" Australopithecines. Aldin de Gruyter, New York, pp. 343-381.

Shipman, P., Phillips, J. E. 1976. On scavenging by hominids and other carnivores. Current Anthropology 17, 170-172.

Shipman, P., Rose, J. J. 1983. Early hominid hunting, butchering and carcass-processing behaviors: approaches to the fossil record. Journal of Anthropological Archaeology 2, 57-98.

Shipman, P., Rose, J. 1984. Cutmarks mimics on modern and fossil bovid bones. Current Anthropology 25, 116-117.

Sikes, N. E. 1994. Early hominid habitat preferences in East Africa: paeosol carbonate isotopic evidence. Journal of Human Evolution 27, 25-45.

Sikes, N. E. 1999. Plio-Pleistocene floral context and habitat preferences of sympatric hominid species in East Africa. In Bromage, T. G., Schrenk, F. (eds.) African Biogeography, Climate Change and Human Evolution. Oxford University Press, Oxford, pp. 301-315.

Simpson, G. G. 1970. Uniformitarianism: an inquiry into principle, theory, and method in geohistory and biohistory. In Hecht, M. K., Steere, W. C. (eds.) Essays in Evolution and Genetics in Honor of Theodosius Dobzhansky. Appleton, New York, pp.43-96.

Skinner, J. D., van Aarde, R. J. 1991. Bone collecting by brown hyaenas Hyaena brunnea in the Central Namib Desert, Namibia. Journal of Archaeological Science 18, 513-5123.

Skinner, J. D., Henshel, J. R., van Aarde, R. J. 1986. Bone-collecting habits of spotted hyenas Crocruta crocruta in the Kruger National Park. South African Journal of Tydskr. Dierk. 21, 303-308.

Smith, B. D. 1977. Archaeological inference and inductive confirmation. American Anthropologist 79, 598-617.

Sorensen, M. V., Leonard, W. R. 2001. Neandertal energetics and foraging efficiency. Journal of Human Evolution 40, 483-495.

Stanley, S. M. 1992. An ecological theory for the origin of Homo. Paleobiology 3, 237-257.

Stiner, M. 1990. The use of mortality patterns in archaeological studies of hominid predatory daptations. Journal of Anthropological Archaeology 9, 305-351.

Stiner, M. 1991. Food procurement and transport by human and non-human predators. Journal of Archaeological Science 18, 455-482.

Stiner, M. 1994. Honor Among Thieves: A Zooarchaeological Study of Neandertal Ecology. Princeton University Press, Princeton. 
Stiner, M. 2002. On in situ attrition and vertebrate body part profiles. Journal of Archeological Science 29, 979-991.

Stiner, M. 2004. A comparison of photon-densitometry and computed tomography parameters of bone density in ungulate body part profiles. Journal of Taphonomy 2(1-4), 117-146.

Suwa, G., Nakaya, H., Asfaw, B., Saegusa, H., Amzaye, A., Kono, R. T., Beyene, Y., Katoh, S. 2003. Plio-Pleistocene terrestrial mammal assemblage from Konso, southern Ethiopia. Journal of Vertebrate Paleontology 23, 901-916.

Tappen, M. 1992. Taphonomy of a central African savanna: natural bone deposition in Parc National des Virunga, Zaire, Ph.D. Thesis. Department of Anthropology, Harvard University, Cambridge.

Tappen, M. 1995. Savanna ecology and natural bone deposition: implications for early hominidsite formation, hunting and scavenging. Current Anthropology 36, 223-260.

Todd, L. C., Rapson, D. J. 1988. Long bone fragmentation and interpretation of faunal assemblages: approaches to comparative analysis. Journal of Archaeological Science 15, $307-325$.

Torre, de la, I. 2002. El Olduvayense de la Seccion Tipo de Peninj (Lago Natron, Tanzania), M.Sc. Thesis. Universidad Complutense, Madrid.

Torre, de la, I. 2004. Omo revisited. Evalating the technological skills of Pliocene hominids. Current Anthropology 45, 439-468.

Torre, de la, I. 2006. Estrategias tecnológicas en el Pleistoceno inferior de África oriental (Olduvai y Peninj, norte de Tanzania). Tesis Doctoral inédita, Universidad Complutense, Madrid.

Torre, de la, I., Mora, R. 2004. El Olduvayense de la Sección Tipo de Peninj (Lago Natron, Tanzania), Vol. 1. CEPAP, Barcelona.

Torre, de la, I., Mora, R. 2005. Unmodified lithic material at Olduvai Bed I: manuports or ecofacts? Journal of Archaeological Science 32, 273-285.

Torre, de la, I., Mora, R., Domínguez-Rodrigo, M., Alcala, L., Luque, L. (2003). The Oldowan industry of Peninj and its bearing on the reconstruction of the technological skills of lower Pleistocene hominids. Journal of Human Evolution, 44, 203-224.

Toth, N. 1982. The stone technologies of early hominids at Koobi Fora, Kenya: an experimental approach, Ph.D. Thesis. Department of Anthropology, University of California, Berkeley.

Toth, N. 1985. The Oldowan reassessed: a close look at Early Stone Age artifacts. Journal of Archaeological Science 12, 101-120.

Treves, A., Naughton-Treves, L. 1999. Risk and opportunity for humans coexisting with large carnivores. Journal of Human Evolution 36, 275-282.

Turner, C. G. 1983. Taphonomic reconstruction of human violence and cannibalism based on mass burials in the American Southwest. In LeMoine, G. M., MacEachern, A. S. (eds.) 
Carnivores, Human Scavengers and Predators: A Question of Bone Technology, University of Calgary Archaeological Association, Calgary, pp. 219-240.

Turner, A., Anton, M. 1997. The Big Cats and their Fossil Relatives. Columbia University Press, New York.

Verdcourt, B. 1963. The Miocene non-marine Mollusca of Rusinga Island, Lake Victoria, and other localities in Kenya. Paleontographica 121, 1-37.

Villa, P., Castel, C., Beauval, C., Bourdillat, V., Goldberg, P. 2004. Human and carnivore sites in European Middle and Upper Paleolithic: similarities and differences in bone modification and fragmentation. Revue de Paleobiologie 23(2), 705-730.

Villa, P., Mahieu, E. 1991. Breakage patterns of human long bones. Journal of Human Evolution 21, 27-48.

Walter, R. C., Manega, P. C., Hay, R. L. 1991. Laser-fusion Ar40/Ar39 dating of bed I, OlduvaiGorge, Tanzania. Nature 354, 145-149.

Walter, R. C., Manega, P. C., Hay, R. L. 1992. Tephrochronology of Bed I, Olduvai Gorge: an application of the laser-fusion 40Ar/39Ar dating to calibrating biological and climatic change. Quaternary International 13-14, 37-46.

Wenzel, G. W. 1995. Ningiqtuq: resource sharing and generalized reciprocity in Clyde River, Nunavut. Arctic Anthropology 32(2), 43-60.

White, T. E. 1952. Observations on the butchering technique of some aboriginal peoples: no.1. American Antiquity 17, 337-338.

Wolpoff, M. H. 1999. Paleoanthropology. McGraw Hill, Madison, Wisconsin.

Wynn, J. G. 2004. Influence of Plio-Pleistocene aridification on human evolution: evidence from paleosols of the Turkana Basin, Kenya. American Journal of Physical Anthropology 123, 106-118. 